Abbas Ibrahim HAMAD ${ }^{1}$

\title{
THE REASONS FOR THE QURAN EXPRESSION IN OPENING AL - QADEER FROM THE SCIENCE OF INTERPRETATION BY AL - SHAWKANI (T. $1250 \mathrm{H}$ )
}

http://dx.doi.org/10.47832/2717-8293.3-3.42

Research Article
Received:
11/02/2021
Accepted:
26/02/2021
Published:
01/03/2021
This article has been
scanned by iThenticat
No plagiarism detected
Copyright $\odot$ Published
by Rimak Journal,
www.rimakjournal.com
Rimar Academy, Fatih,
Istanbul, 34093 Turkey
All rights reserved

\begin{abstract}
:
This research is meant to collect the faults of the Quranic expression vocabulary - and study them selectively.

After trusting in God Almighty. The book (The Almighty conguest of Tafsir science of shawkani) to be amodel And atopic of my research entitled b (The reason for the Quran expression in the opening of alQadeer from the science of exegesis of shawkani At the end of $1250 \mathrm{~h}$ ), to introduce the noble reader to one of the thirteenth century flags and to acguaint him with 1 show him about the reasons for the Holy Quran assigning some expressions and preferring some of then to others. And repeating it, and 1 decided that the search should be in three areas:

The first: Spesification in terms and includes: (its purposes, themes and methods).

The second: Altruism in words and includes: (nouns, verbs,letters).

The third: Refining in expressions and includes: (nouns, verbs, letters). And while the mabahith presented it from the reason for the Quran expression in the interpretation of "the mighty conguest"it also followed Expressions that other scholars have in their commentaries: Based on it, and then came the concubine to show The results of the research. .

Key words: The Causes of Expression, The Qur'anic Expression, The Science of Exegesis, The Shawakani.
\end{abstract}

${ }^{1}$ Dr. , Iraq, abbasabrahem446@gmail.com 


\title{
علل التعبير القرآنيّ في فتح القدير من علم التفسير للشَّوكانيّ (ت1250هـ)
}

\section{عبَّاس إبراهيم حمد 2}

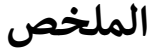

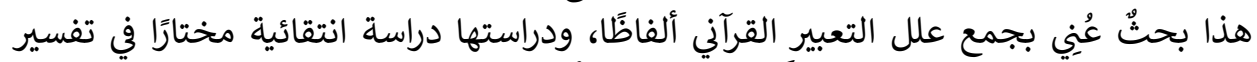

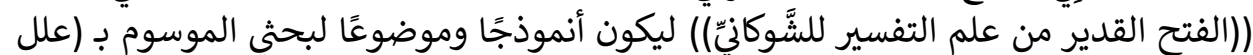

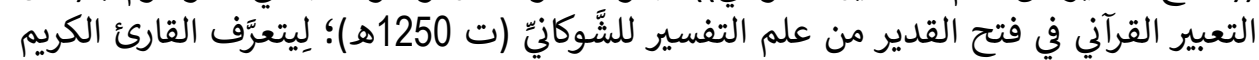

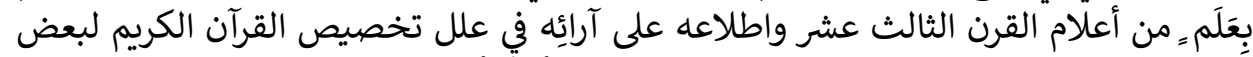

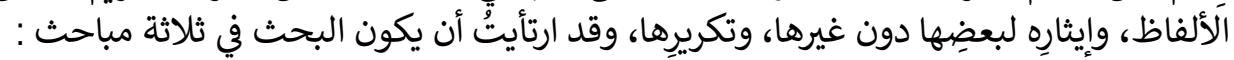

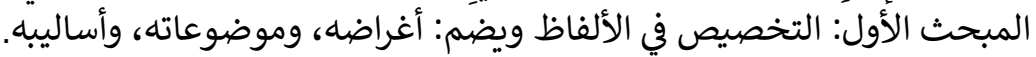

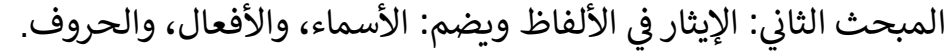

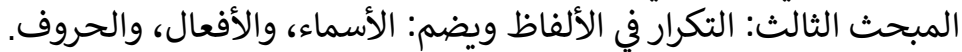

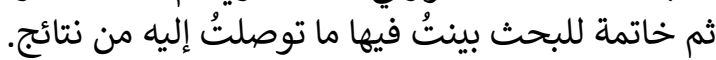

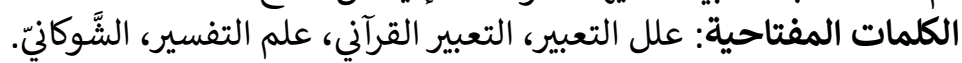

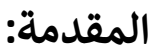

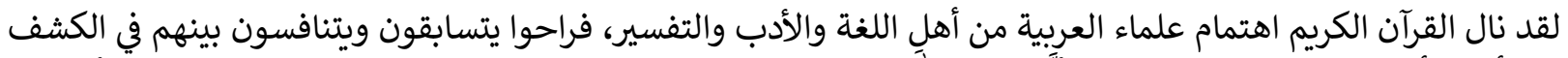

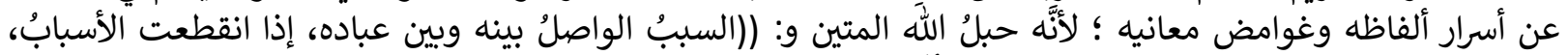

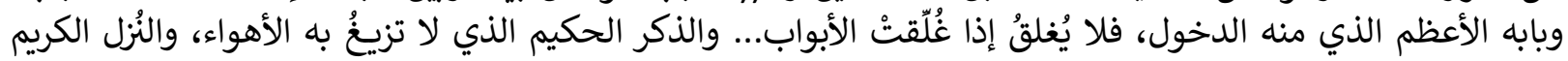

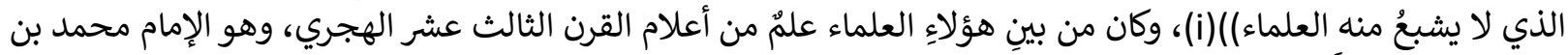

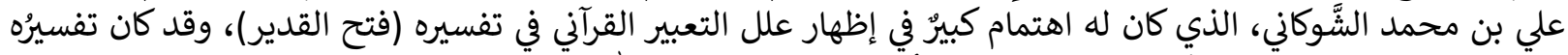

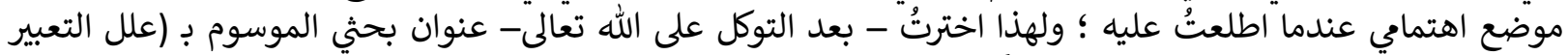

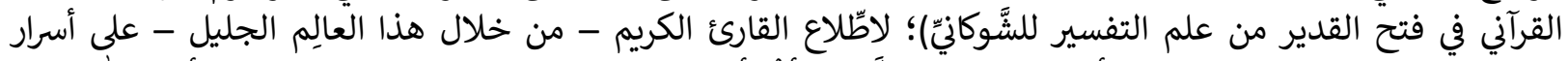

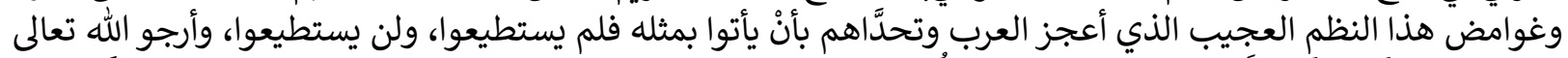

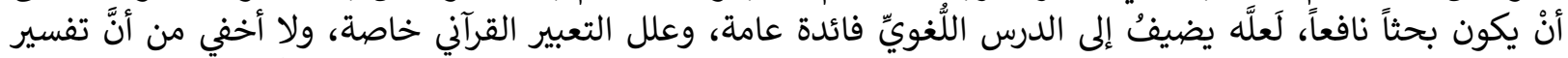

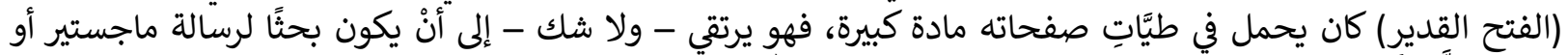

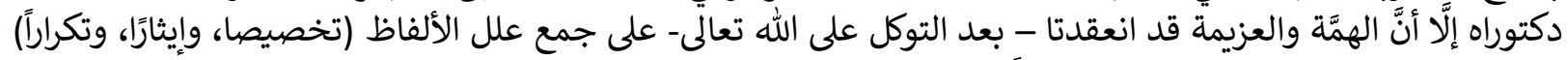

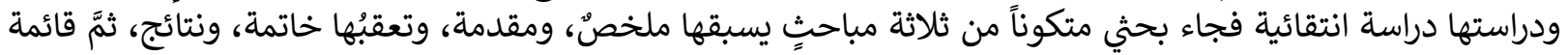

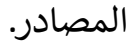

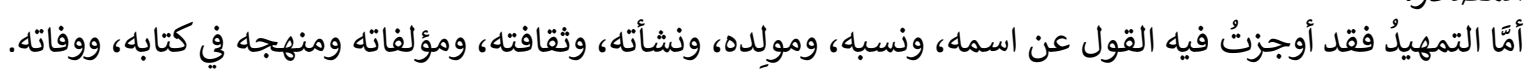

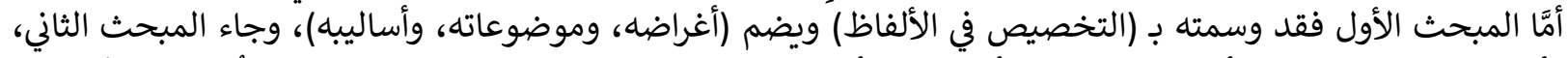

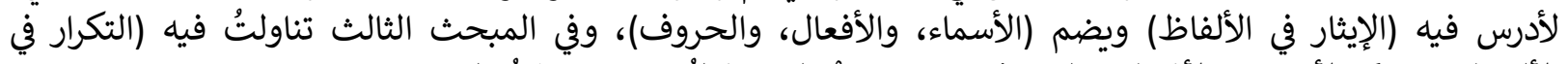

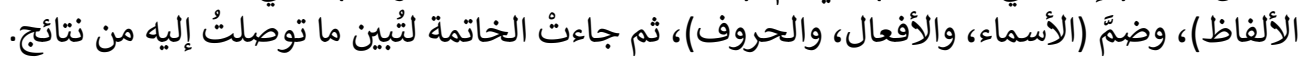




\section{التمهيد \\ اسمُه ونسبُه:}

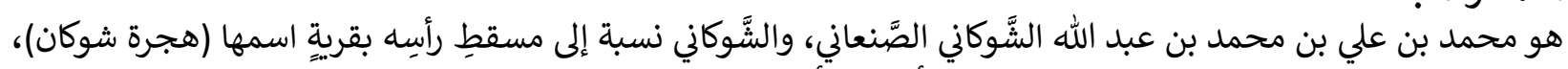

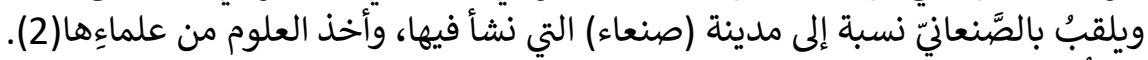

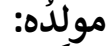

ذكرَت المصادرُ أنَّ الشَّوكانيّ قد وُلد بقرية (هجرة شوكان) إحدى قُرى اليمن في شهرِ ذي القعدة سنة ألفٍ وسبعمائةٍ وثلاثٍ

وسبعين للهجرة(3).

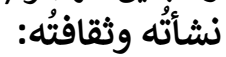

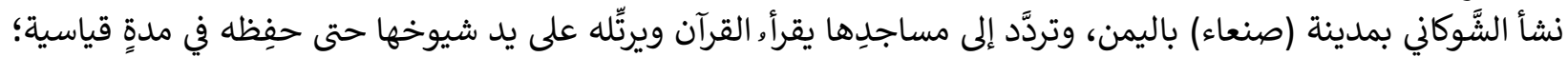

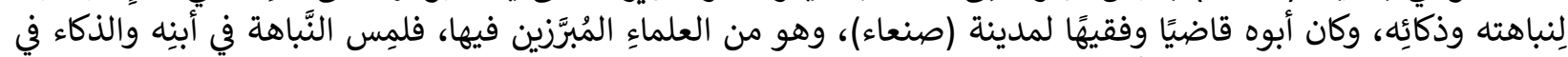

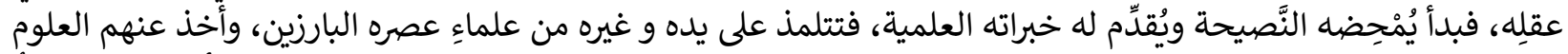

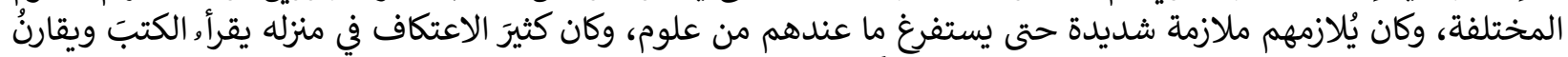

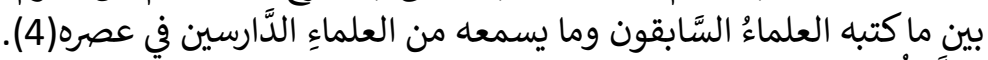
مؤلَّفاتُه:

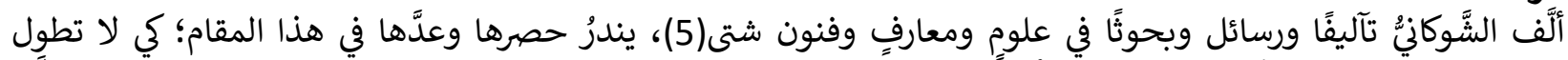

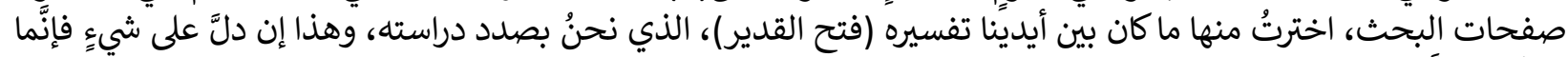

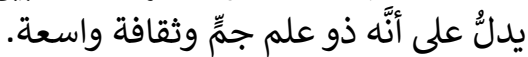

منهجُه في كتابه:

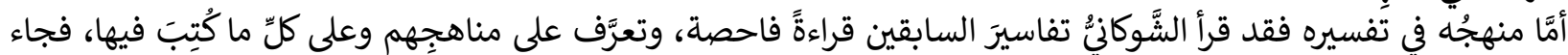

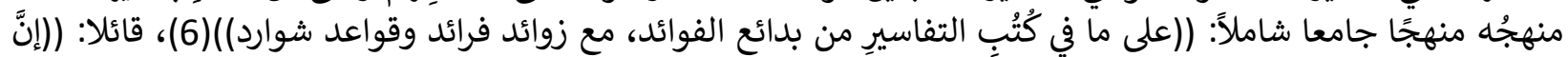

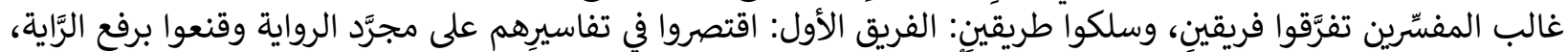

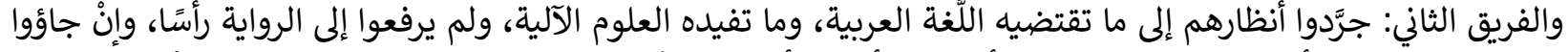

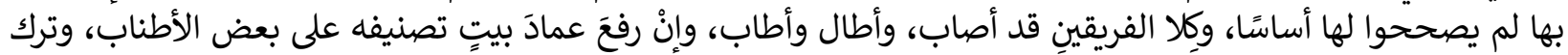

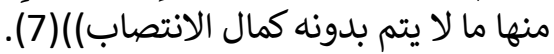

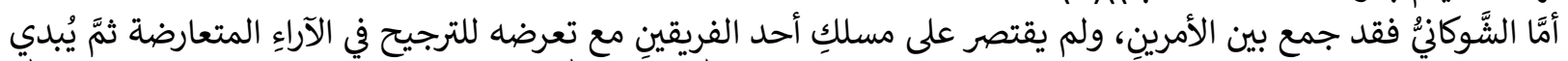

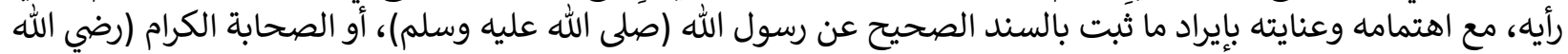

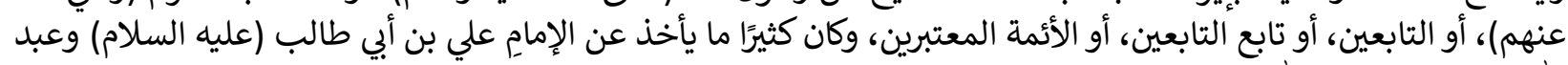

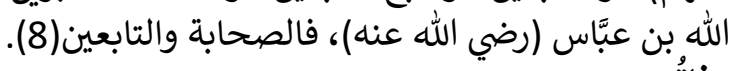

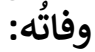
ذكرت المصادرُ التي ترجمت للإمام الشَّوكاني أنَّهَ توفاه الله تعالى سنة ألفٍ ومائتينِ وخمسين من الهجرة في جمادى الآخرة ودُفن بمقبرة خزيمةً بصنعاء (9).

\section{المبحث الأول: علل التخصيص في الألفاظ}

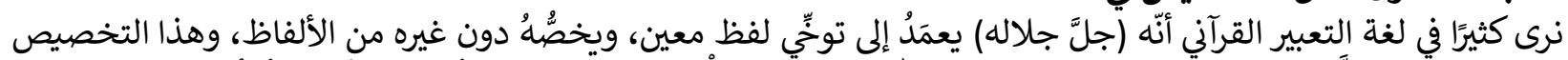

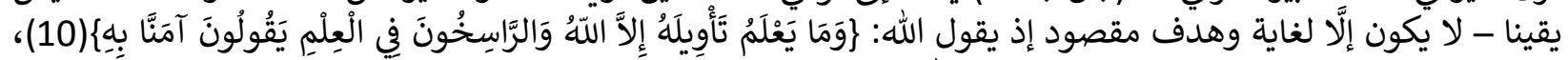

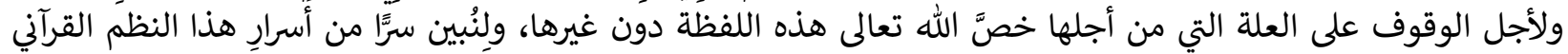

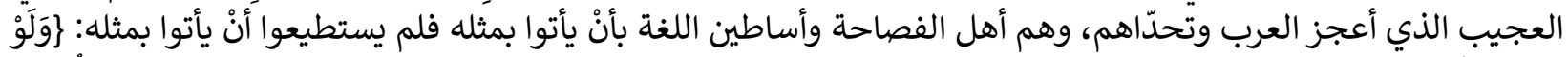

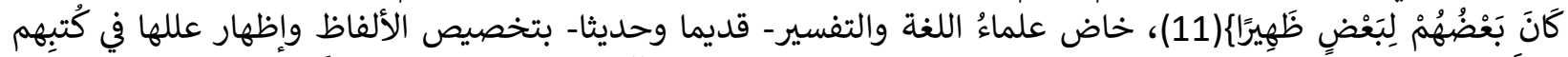

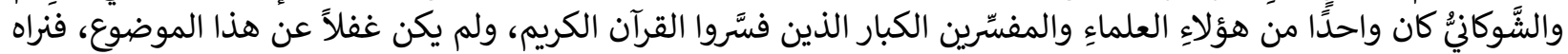

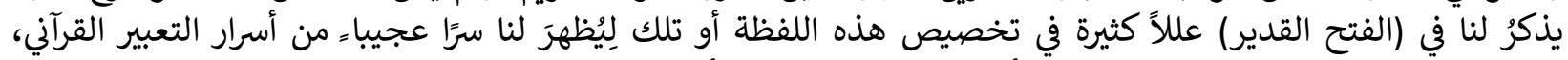

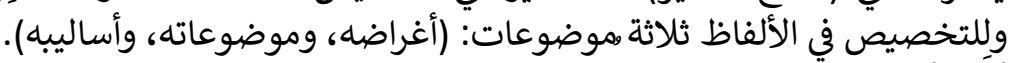

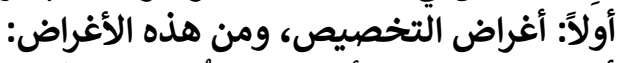

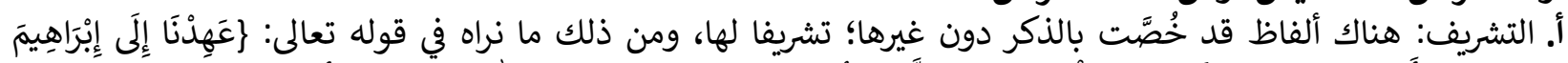

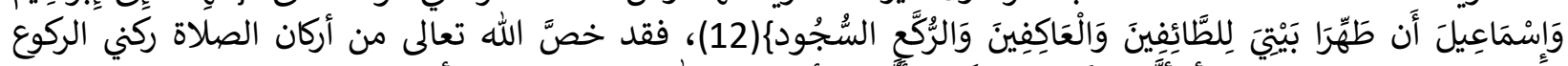

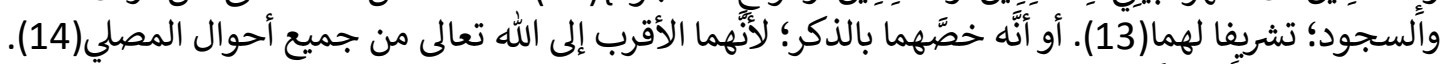

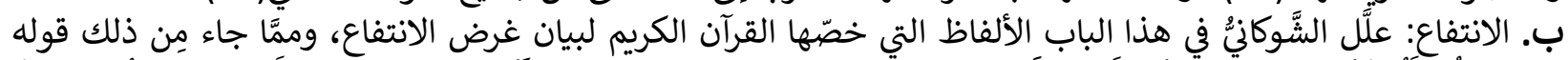

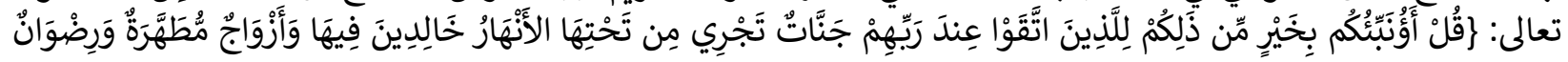




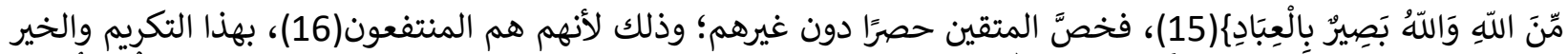

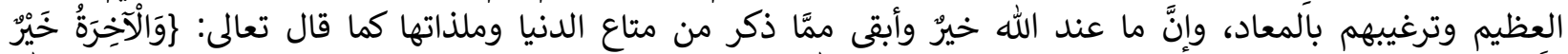

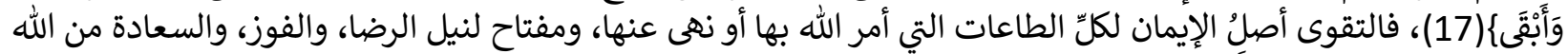

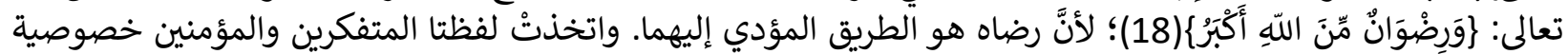

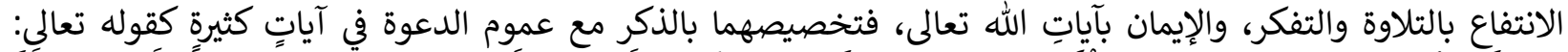

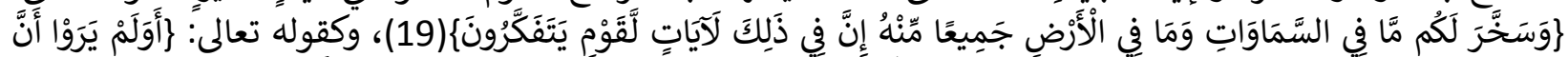

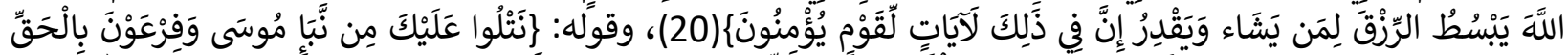

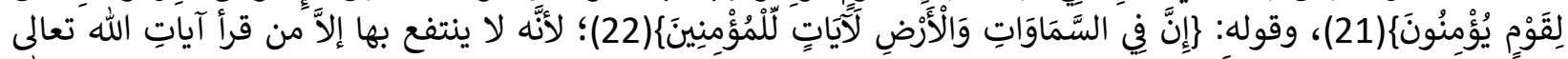

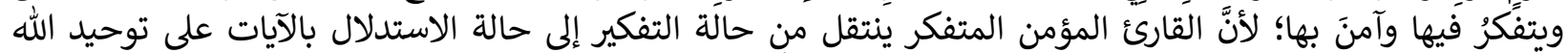

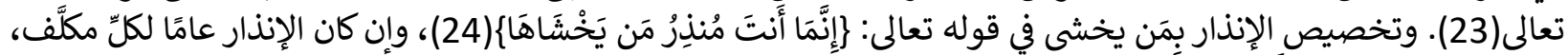

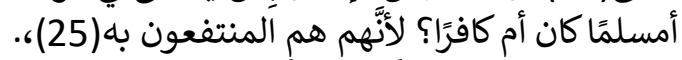

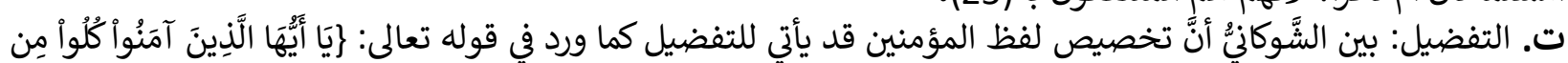

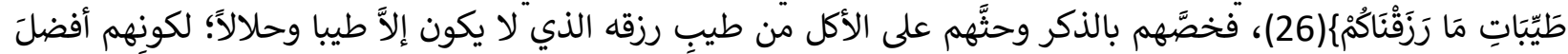
أنواع الناسِ(27).

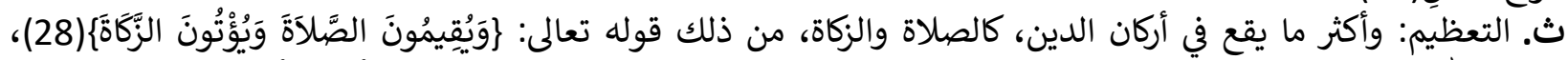

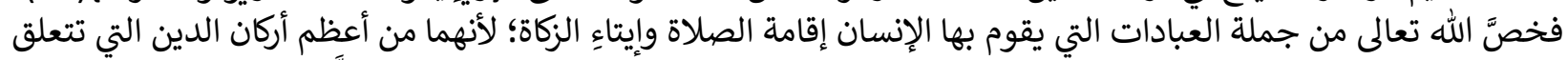

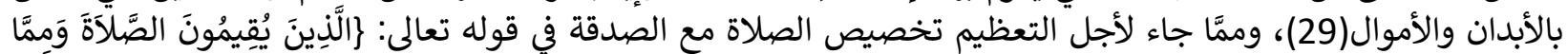

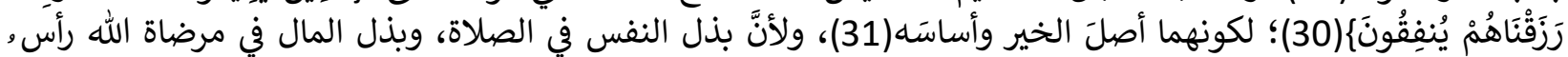

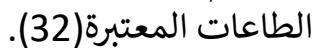

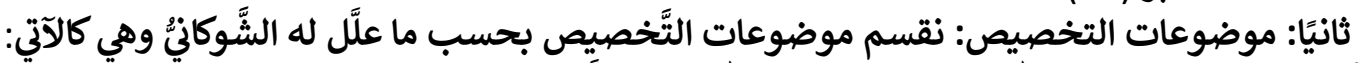

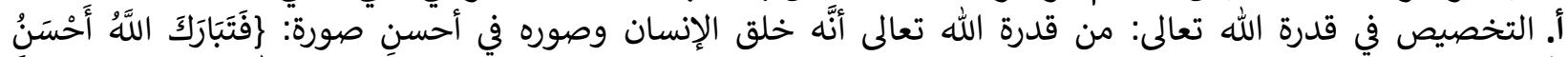

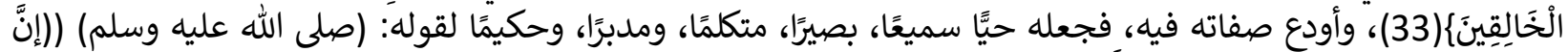

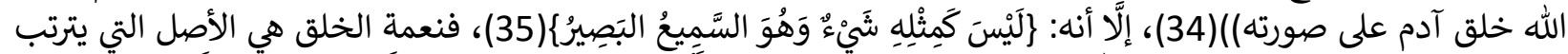

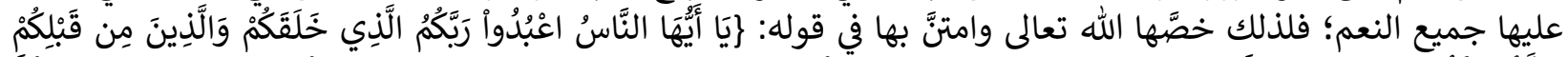

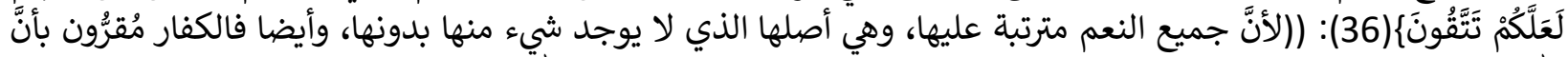

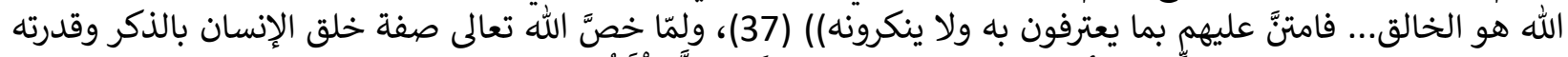

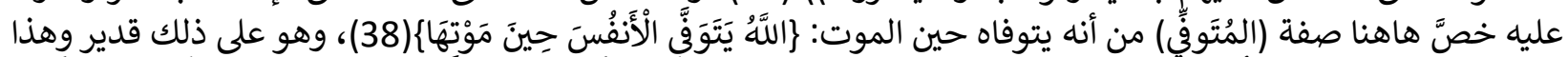

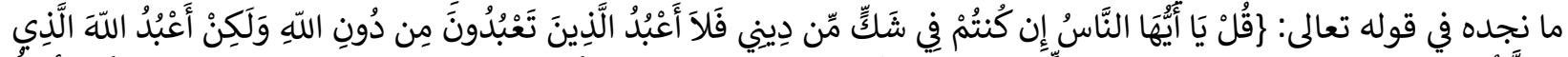

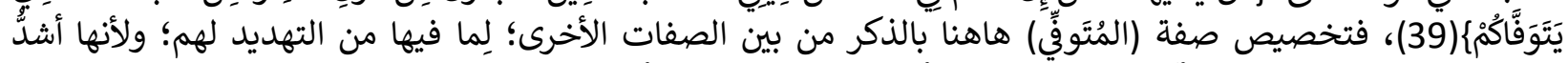

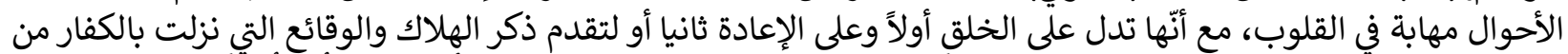

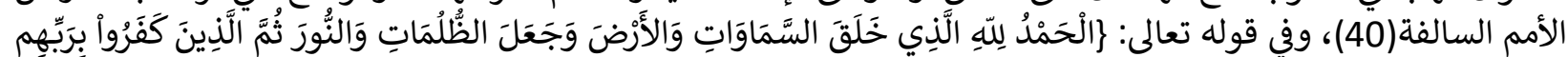

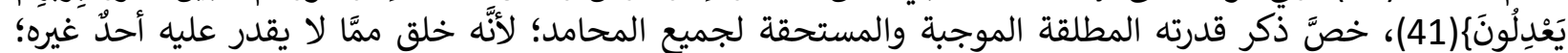

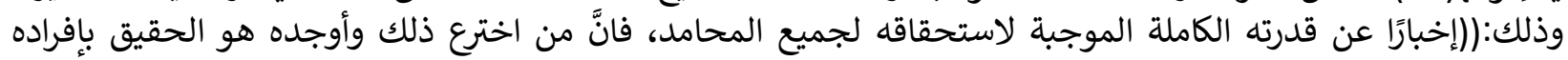

بالثناء وتخصيصه بالحمد)(أخداء (42).

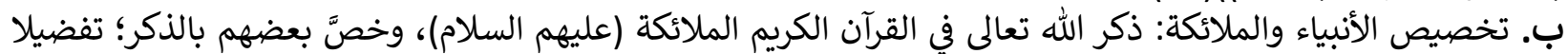

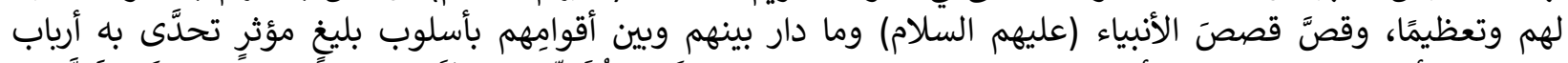

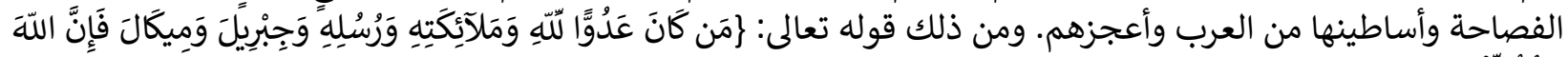

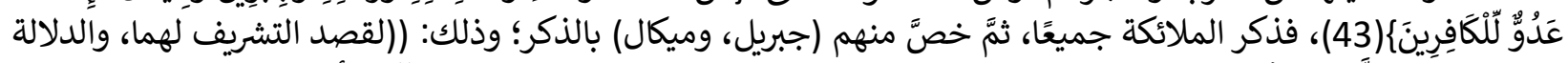

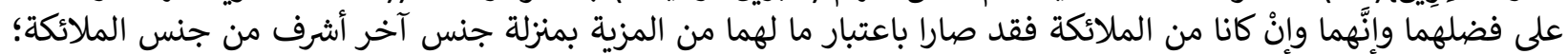

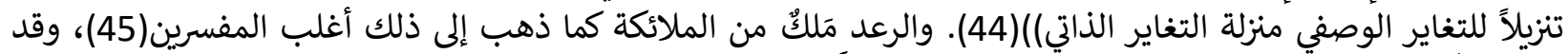

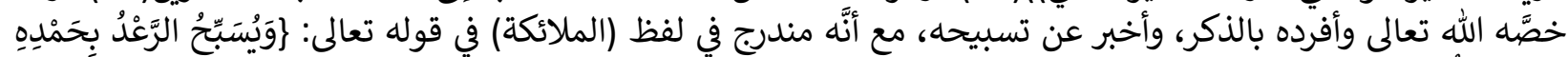

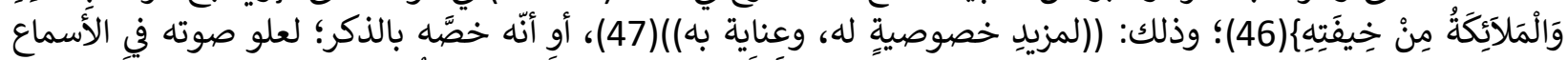

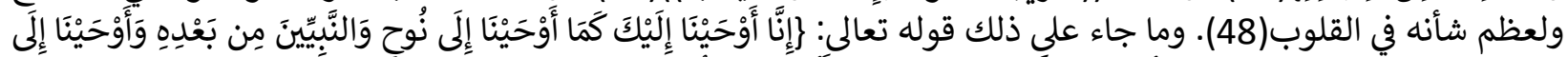

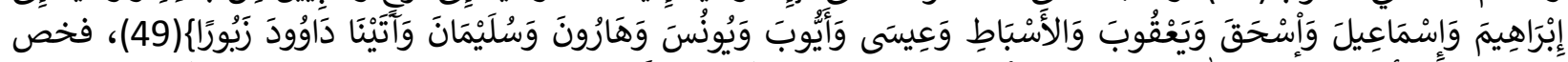

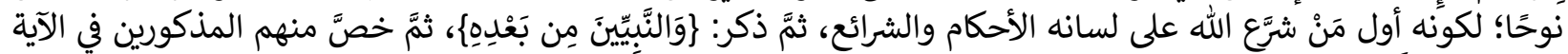

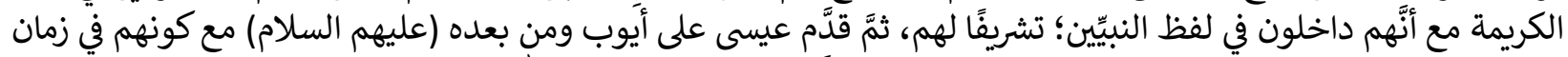

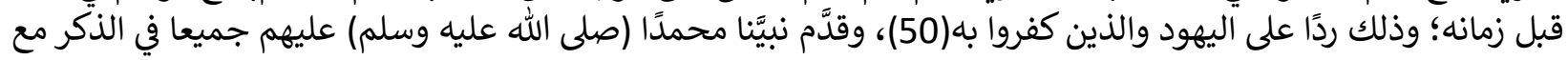




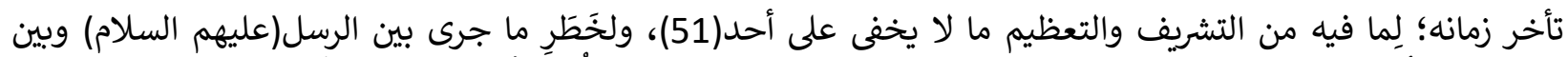

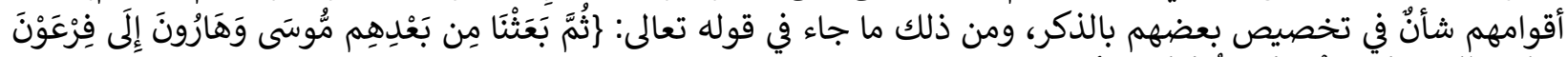

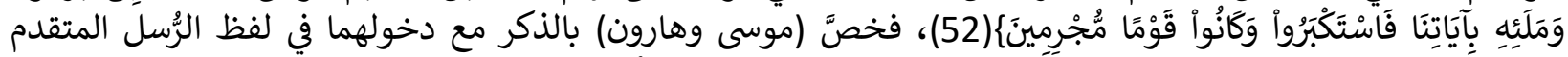

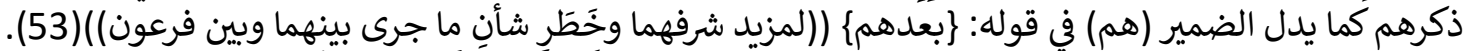

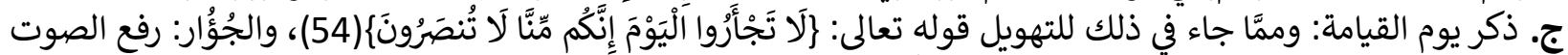

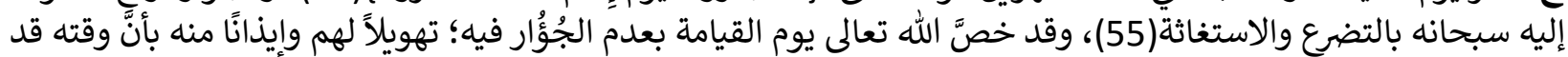

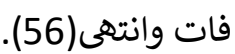

د. ذكر الإنسان وما يتعلق به: خصَّ الله تعالى في كثير من الآيات الكريمة ذكر الإنسان بذاته وقراباته وحالاته وما يتعلق به

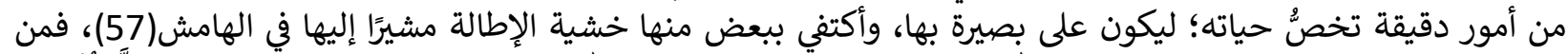

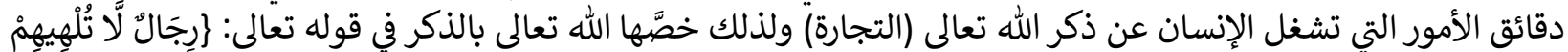

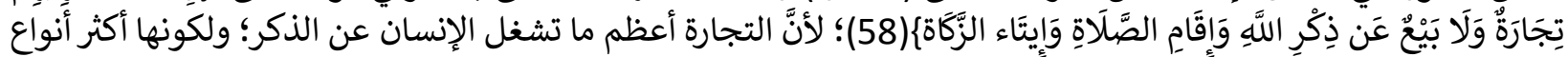

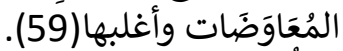

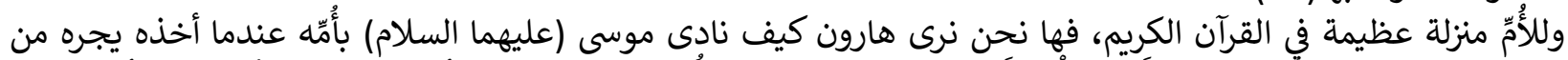

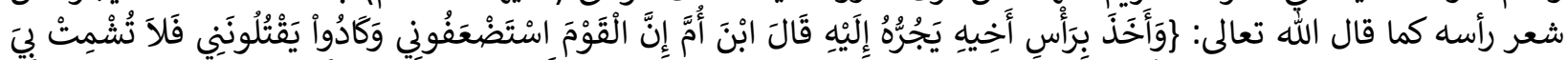

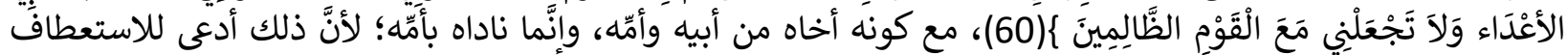

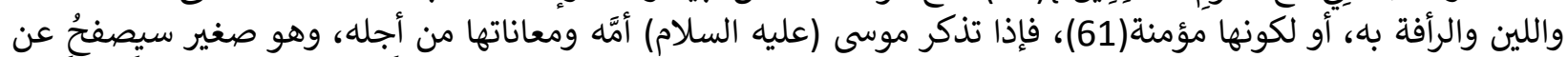

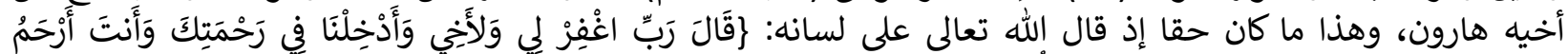

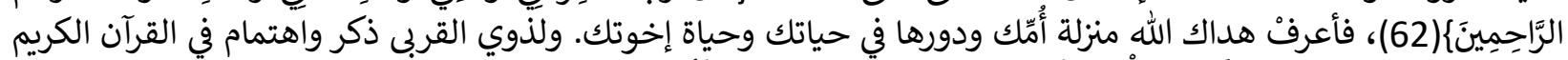

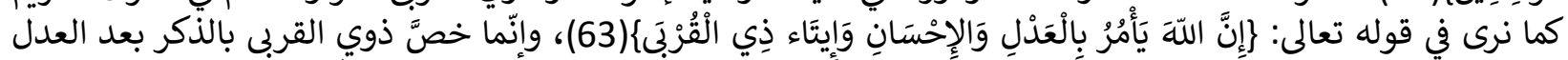

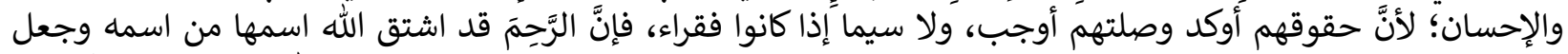

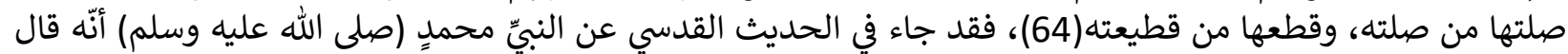

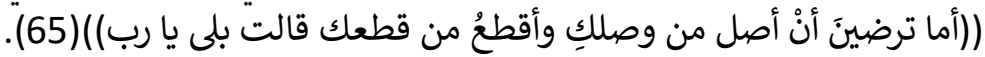

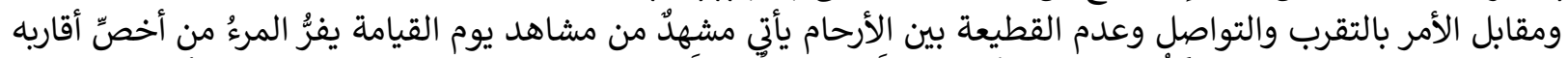

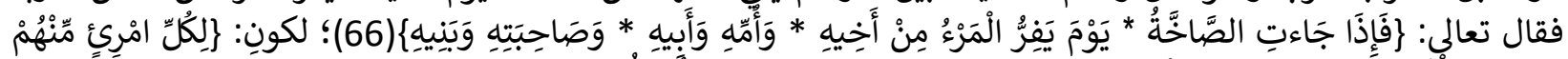

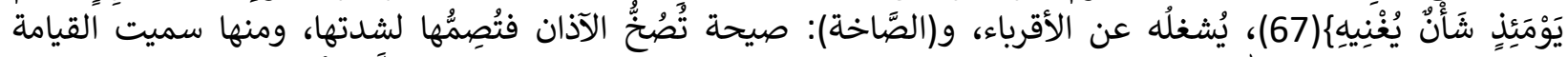

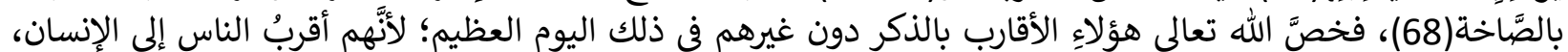

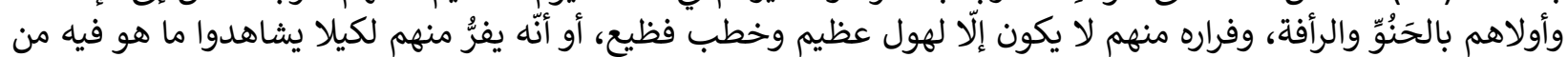

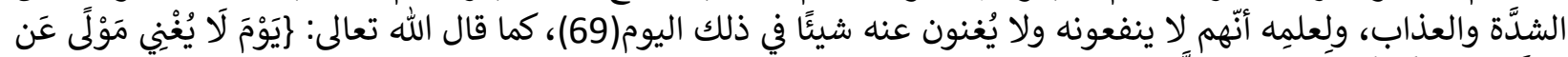

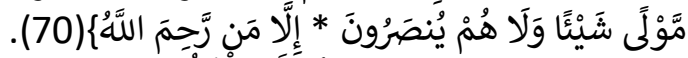
وَفي قوله تعالى

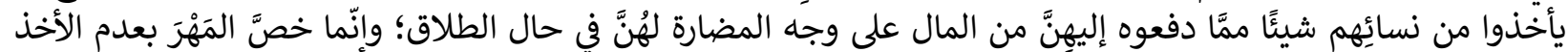

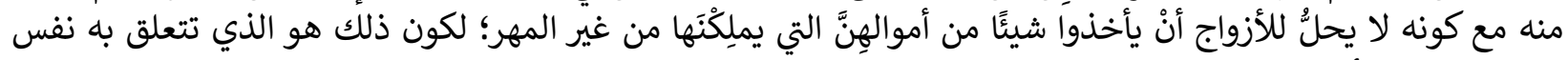

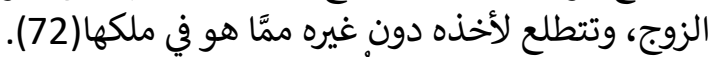

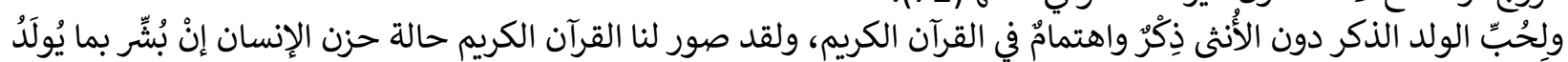

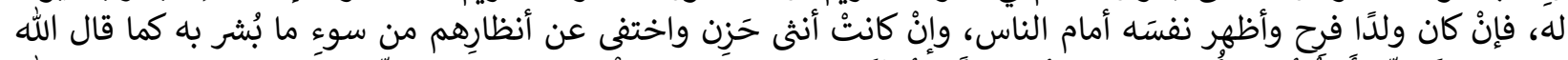

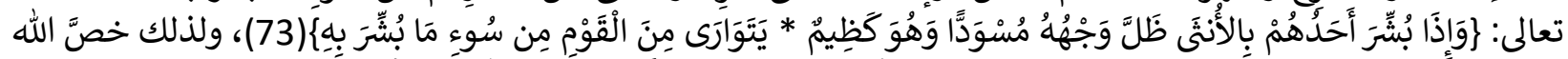

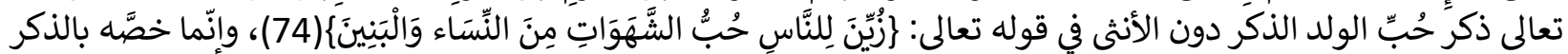

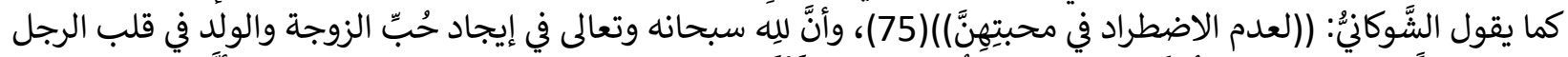

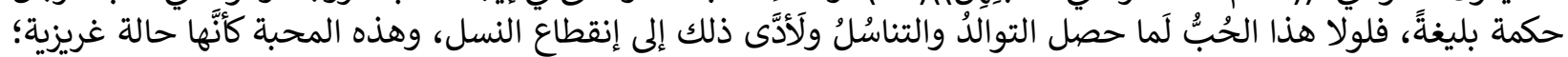

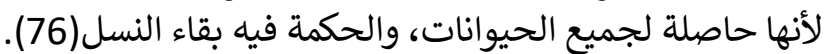

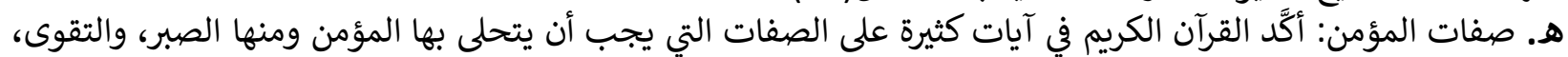

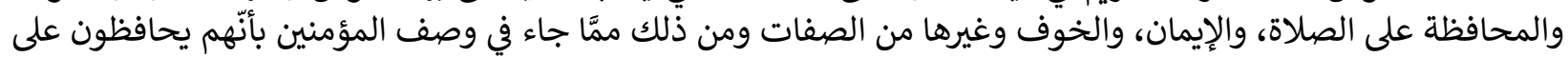

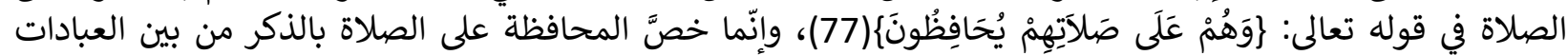

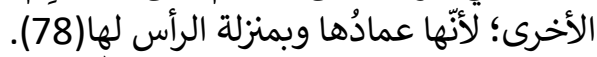

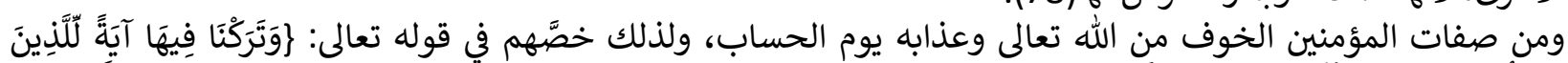

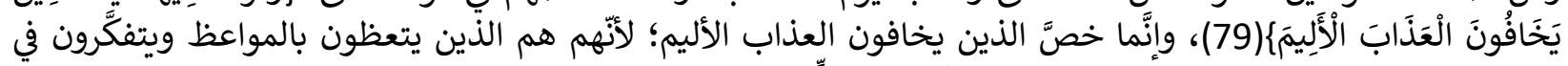

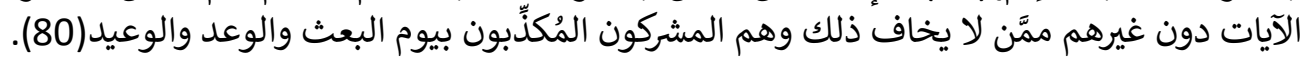




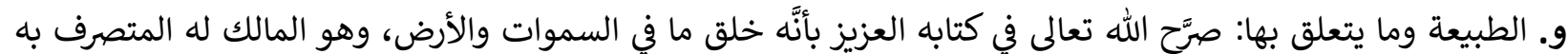

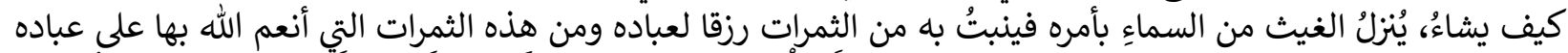

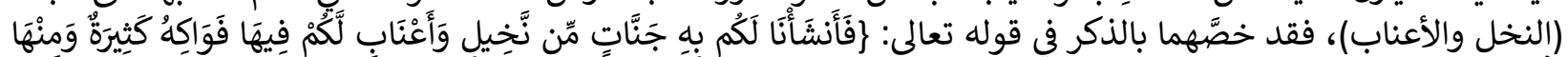

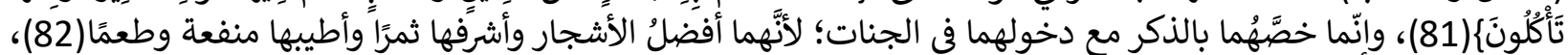

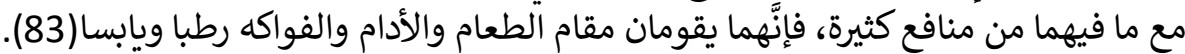

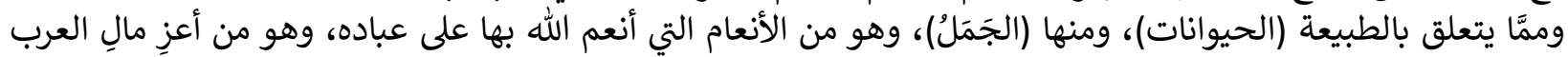

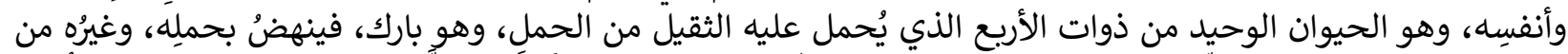

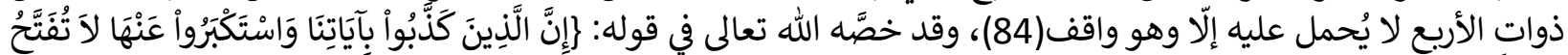

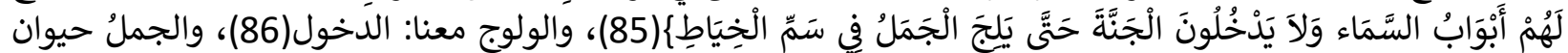

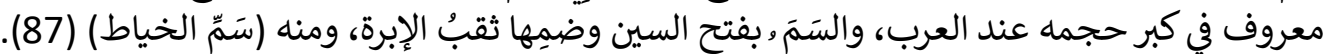

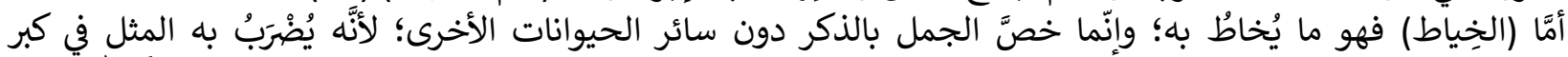

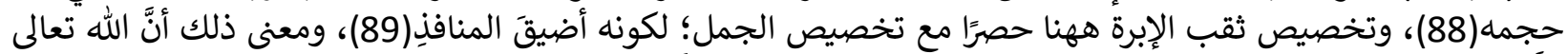

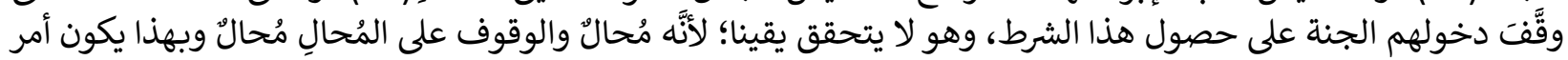
دخولهم الجنة مستحيلا ومَيؤساً منه(

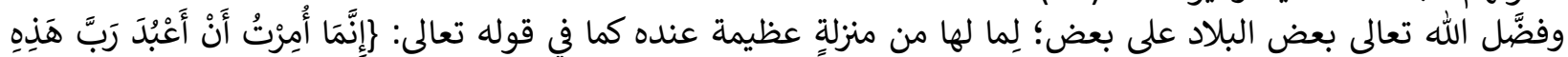

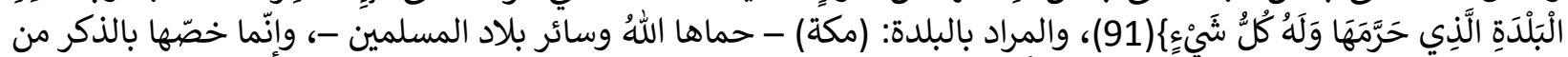

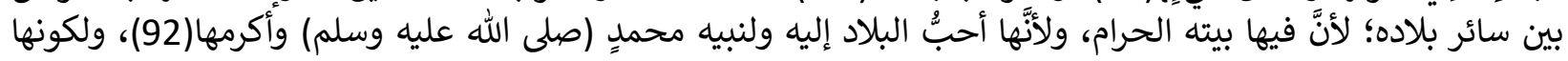

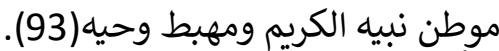
ثالثًا: أساليب التخصيه الكريم ومهيط وحئية

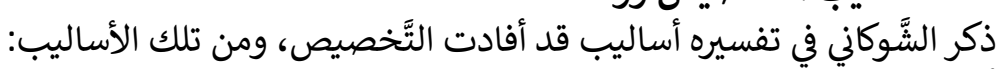

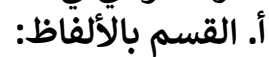

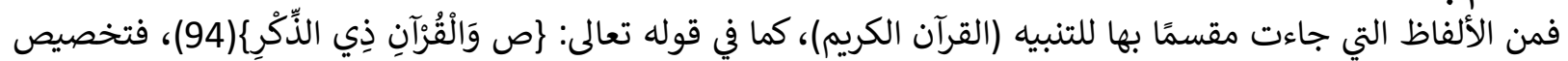

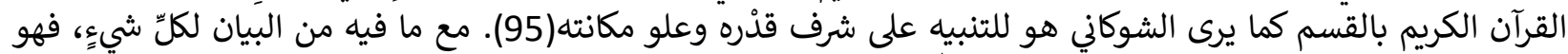

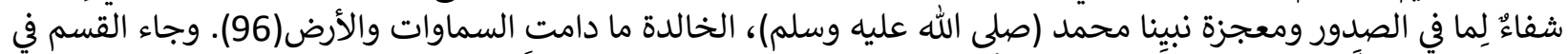

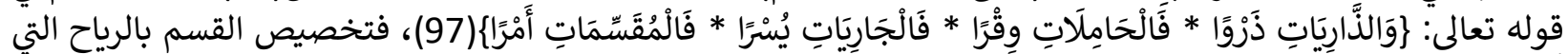

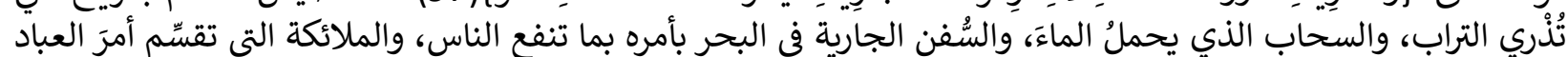

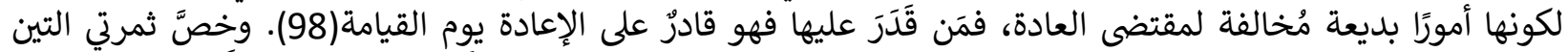

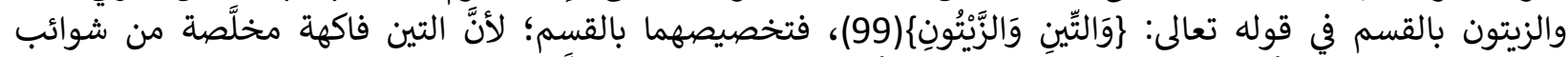

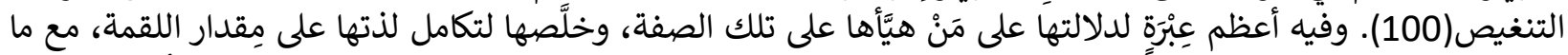

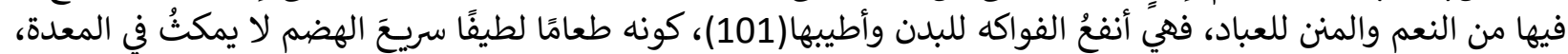

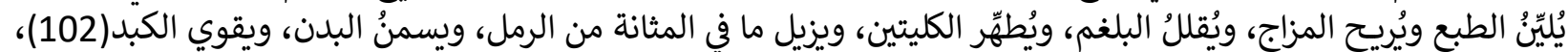

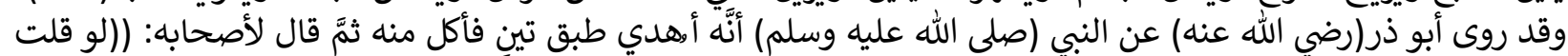

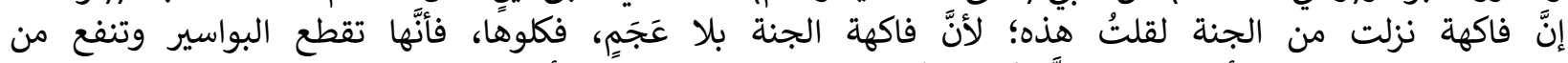

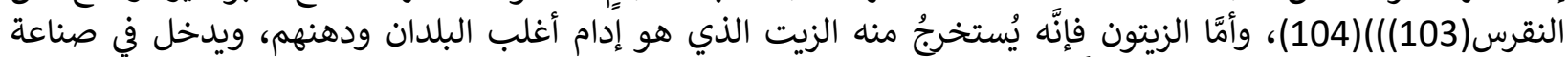

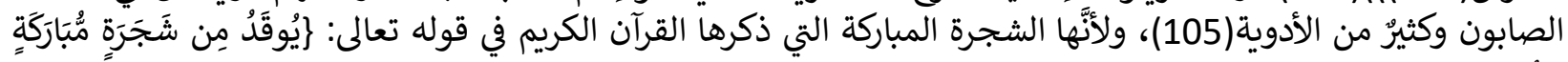

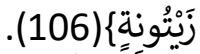

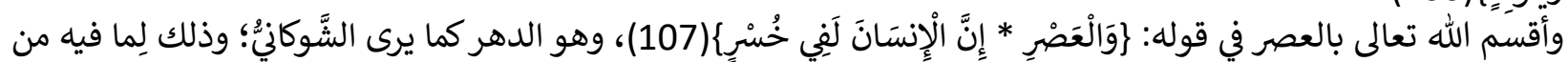

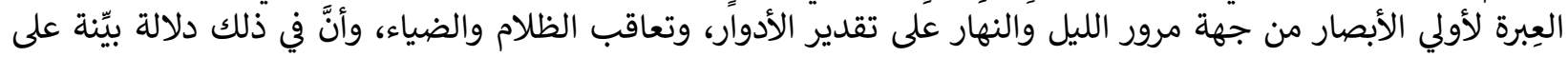
الصانع عز وجل وعلى توحيده(108) الأصار من جرول العيل

ب. العموم والخصوص:

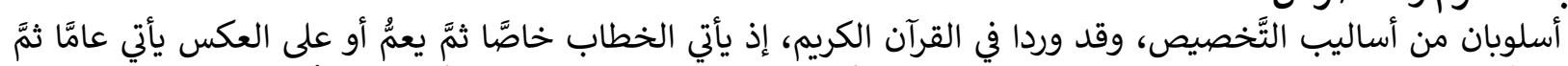

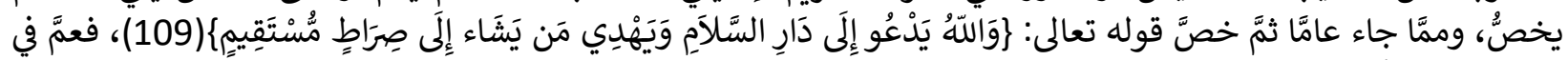

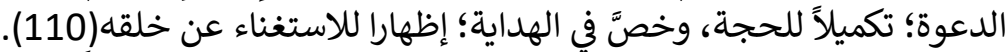

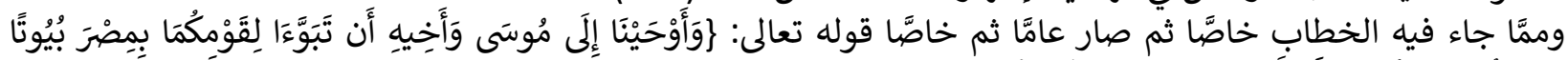

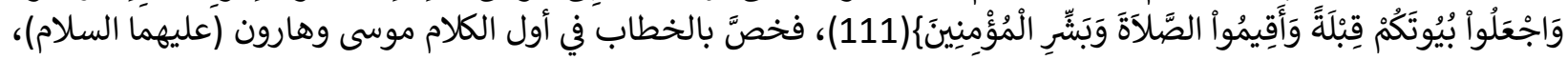




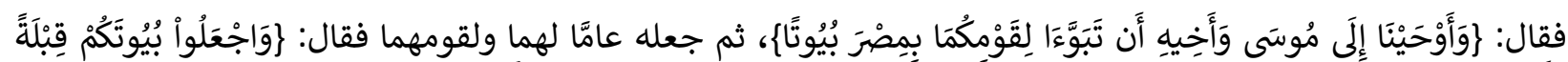

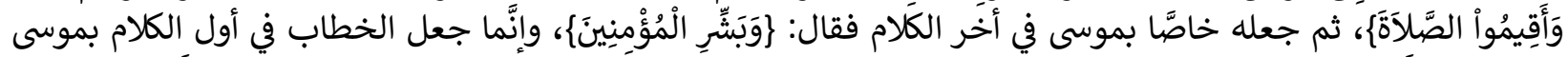

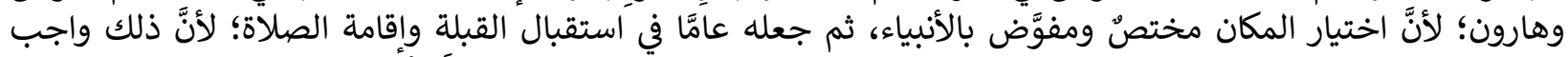

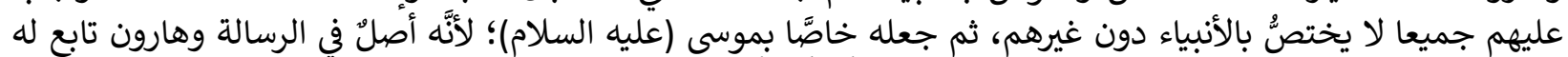

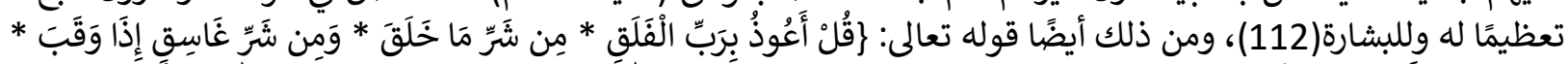

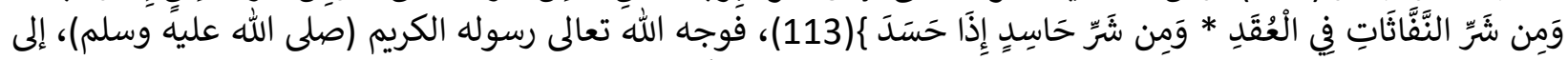

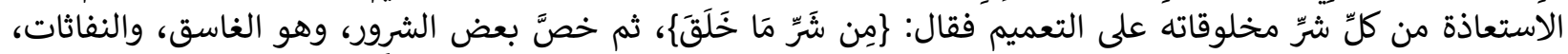

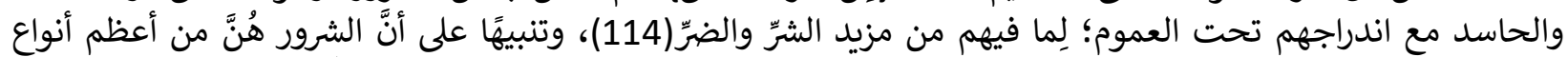

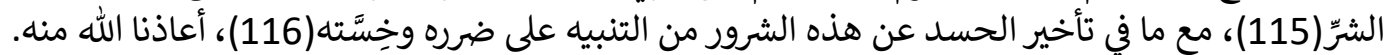

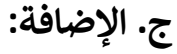

هي إحدى الإضافة وسائل التخصيص التي قد وردت في القرآن الكريم، ويمكن دراستها بحسب تعليل الشَّوكانيٌ لها في تفسيره من جأنبين: - (إنان

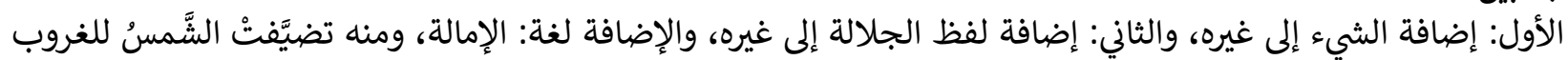

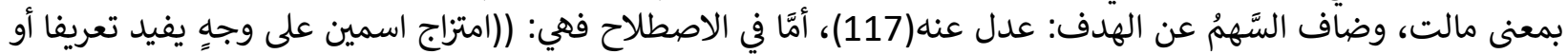

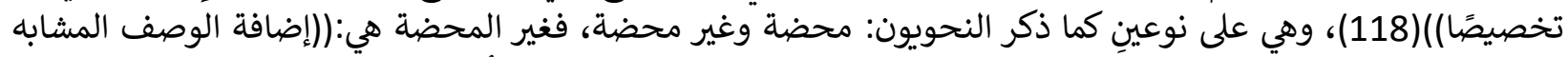

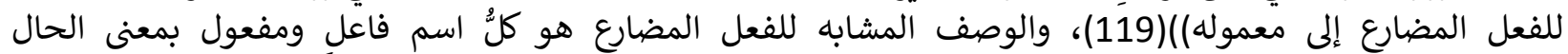

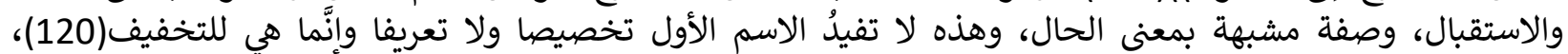

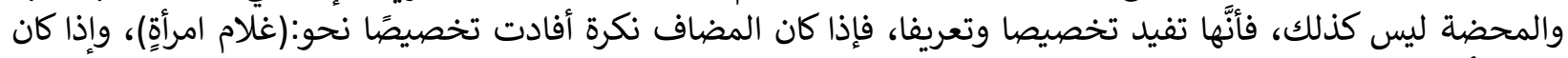

معرفة أفادت تعريفا نحو:(غلامُ زيدٍ)(121).

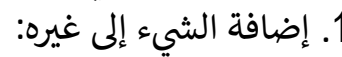

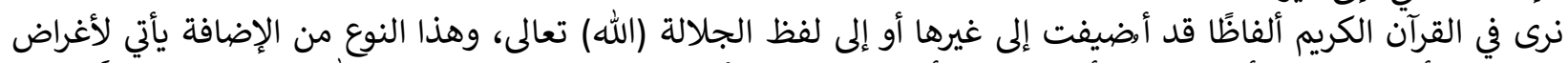

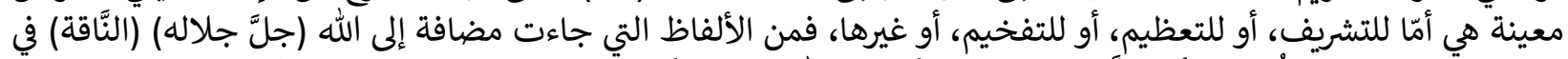

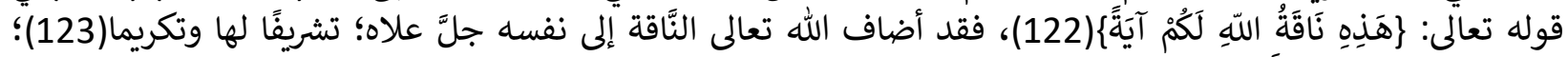

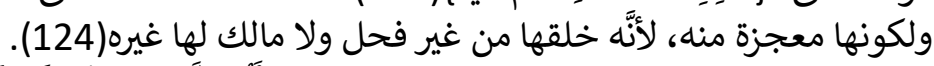

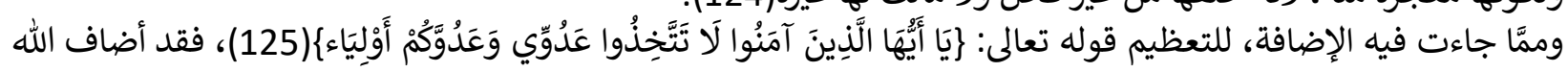

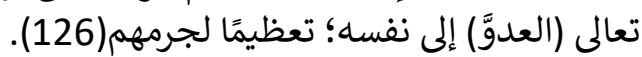

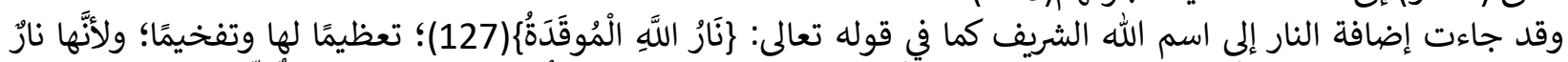

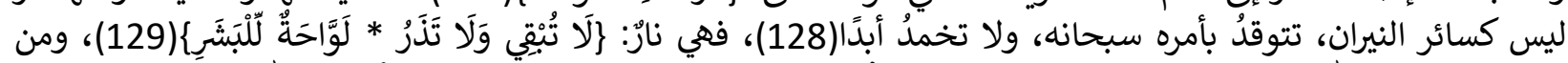

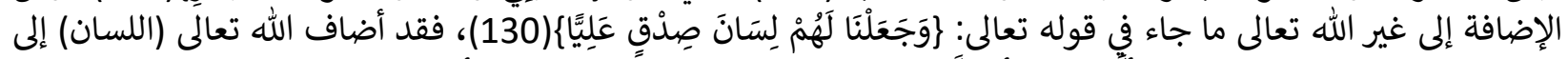

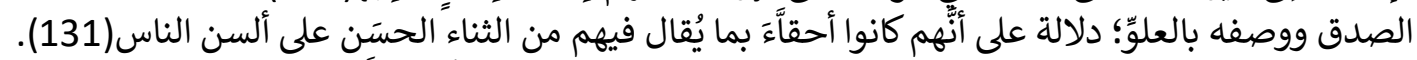

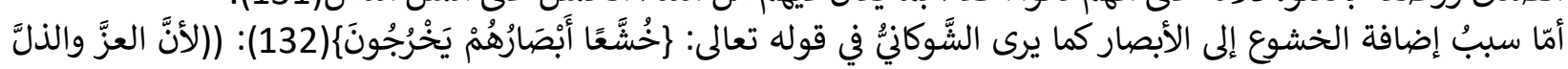
يتبين فيها)(إ)(133).

2. إضافة لفظ الجلالة إلى غيره:

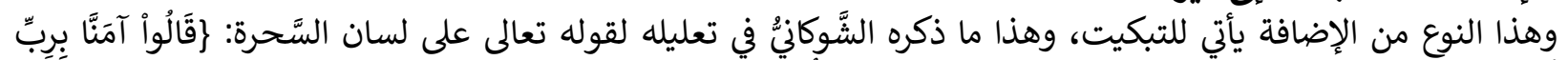

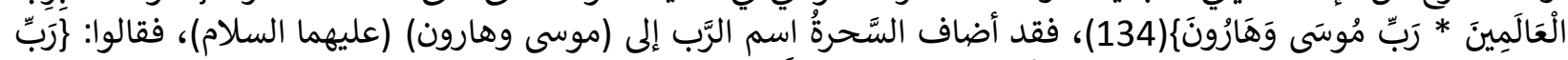

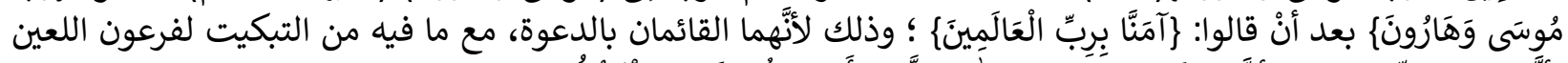

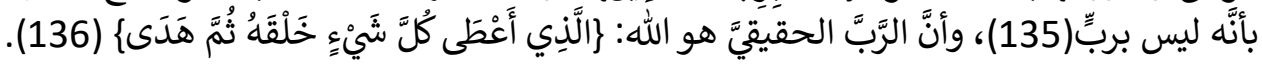

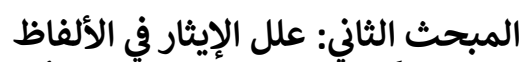

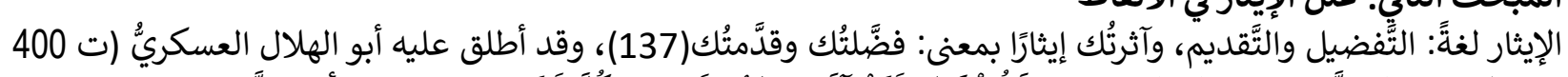

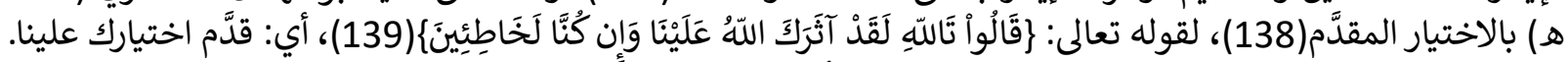

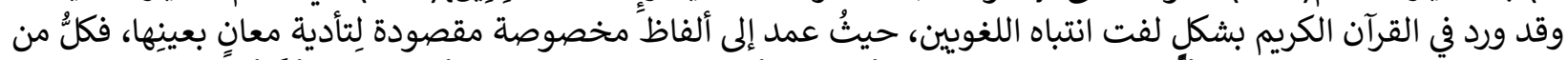

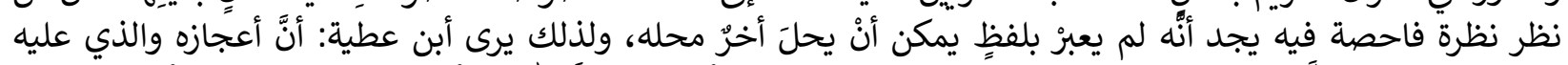

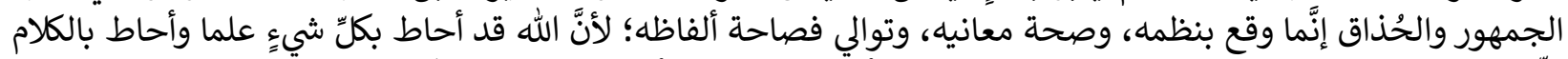

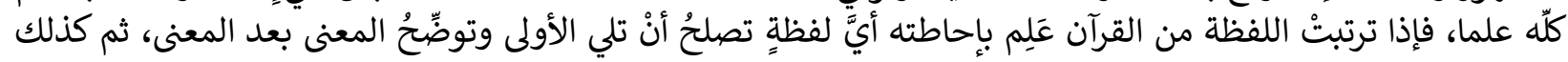




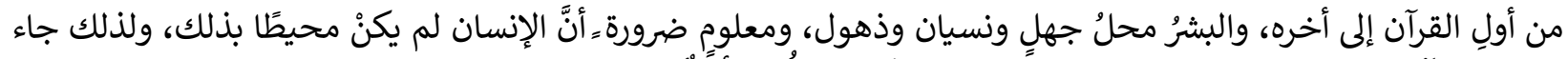

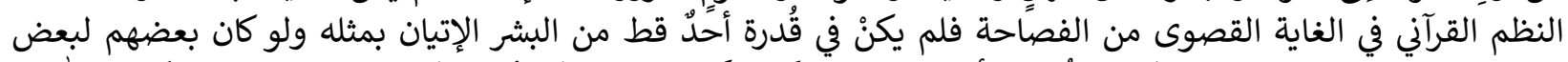

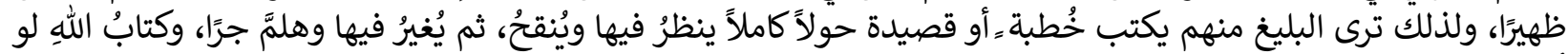

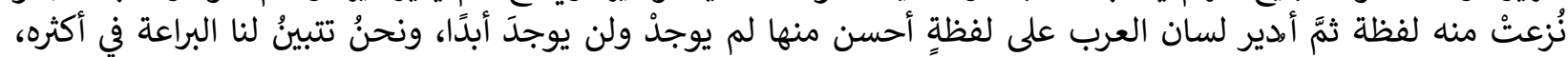

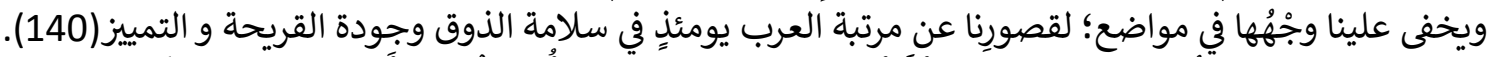

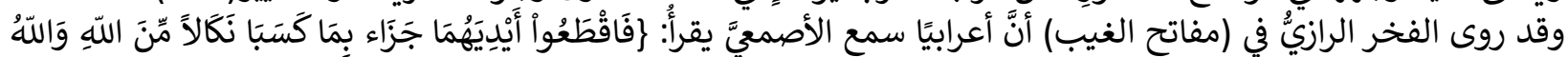

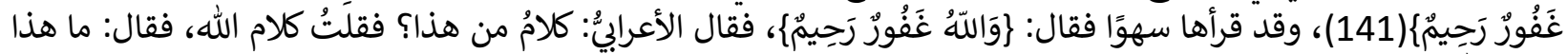

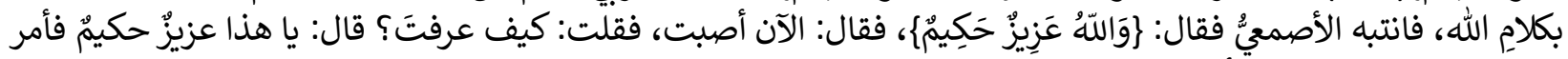

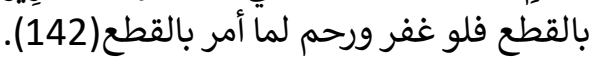

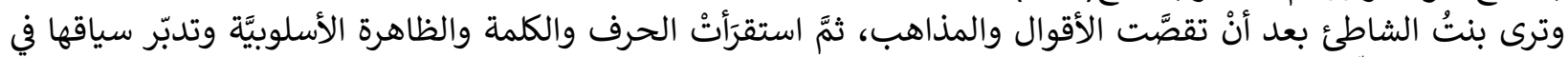

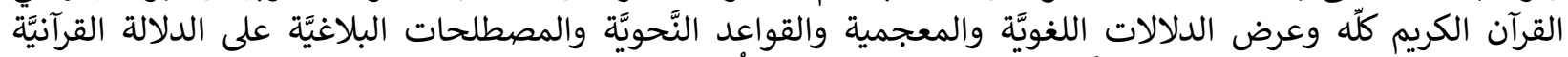

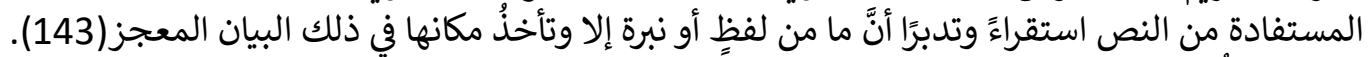

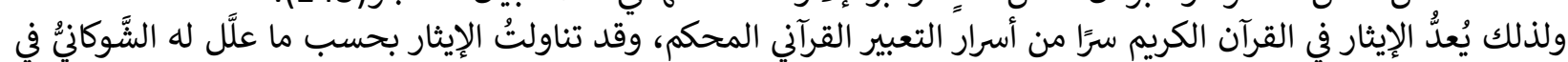

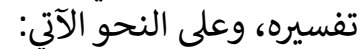

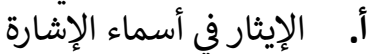

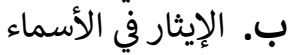

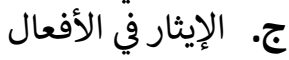

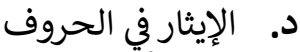

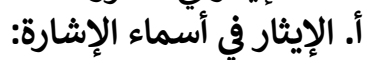

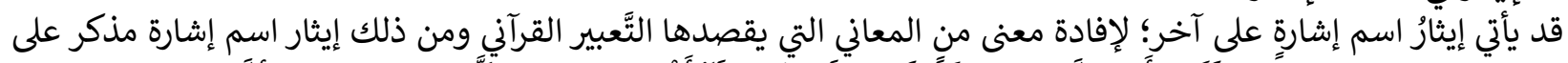

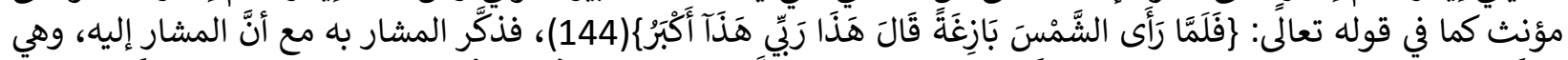

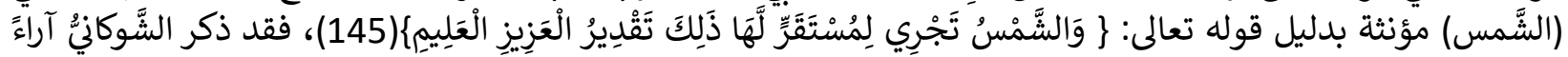

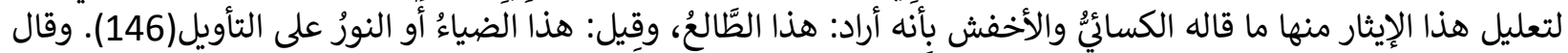

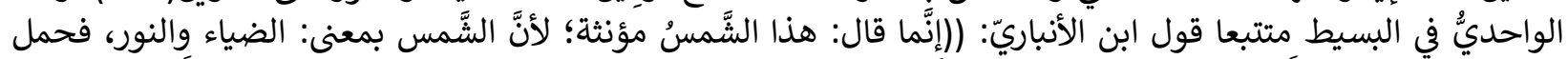

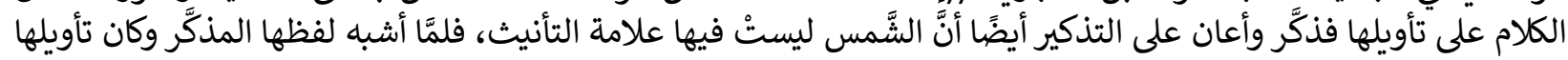

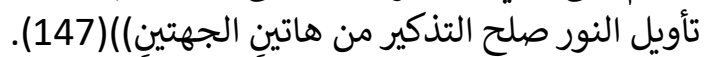

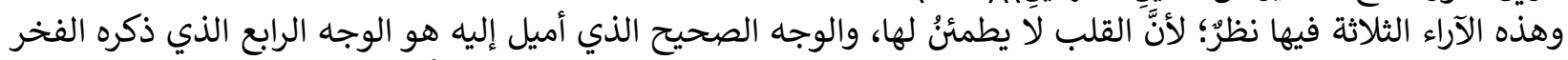

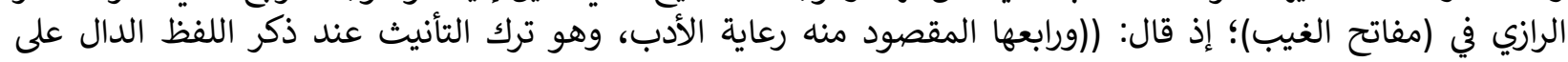

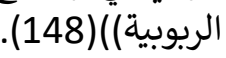
وقد يأتي استعمال أسماء الإشارة في النص القرآني لإفادة معانٍ دقيقة منها: التَّعظيم والتَّهويل والتَّفخيم في الشأن، أو بعد المنزلة في الفظاعة.

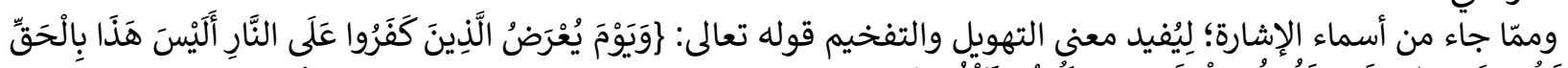

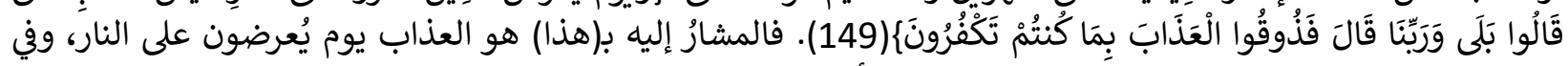

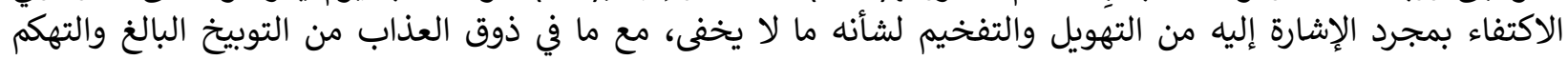

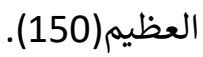

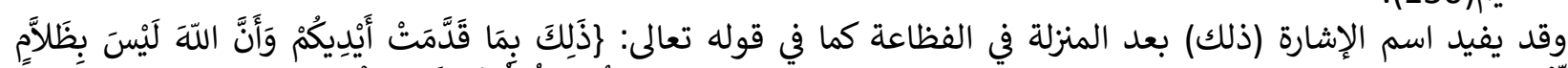

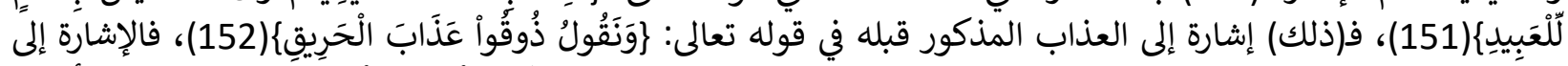

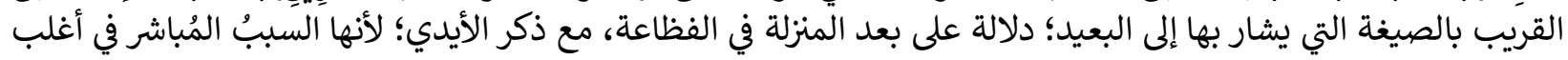

المعاصي(153).

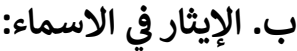

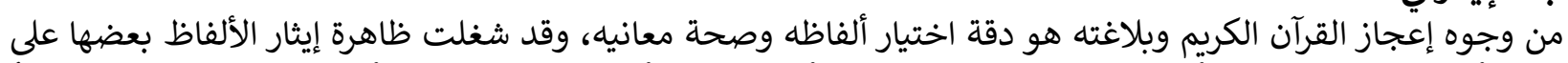

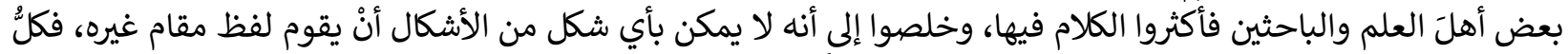

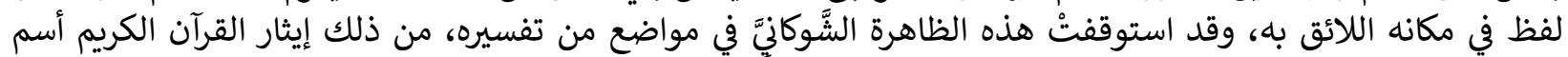

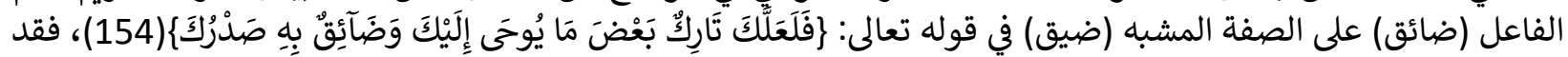

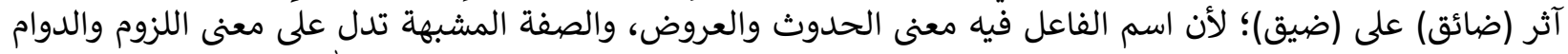
والاستمرار في صاحبها (155)، والخطاب (آن ولا شك في الآية الكريمة موجه إلى سيدِنا محمدٍ (صلى الله عليه وآله وسلم) ويقينا 
أنَّه كان أفسح الناس صدرًا، ليدلّ على أنَّهَ ضيق عارض وزائل، إضافة إلى ذلك أنَّ أنَّ الله تعالى قد نهاه

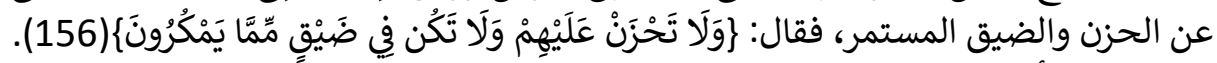

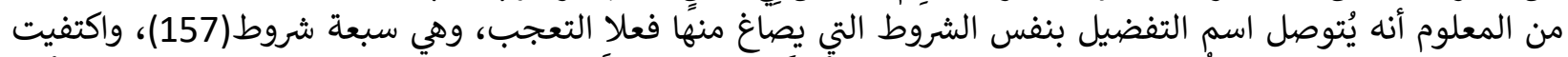

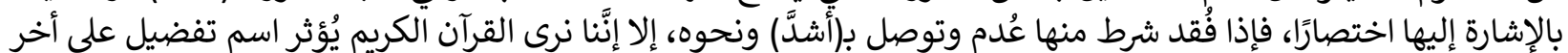

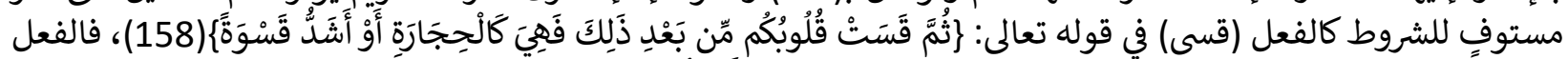

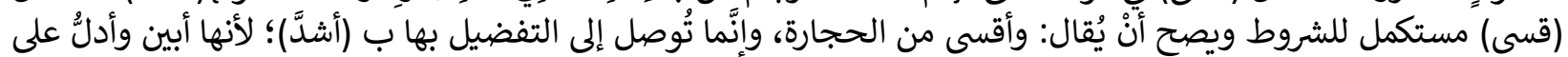
فرط القسوة(159). (159).

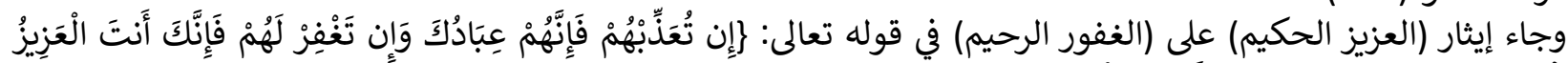

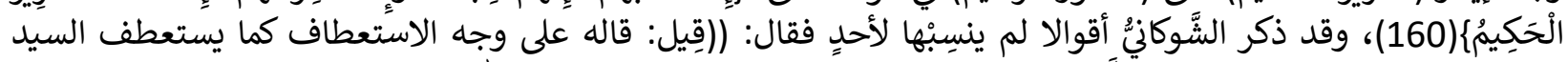

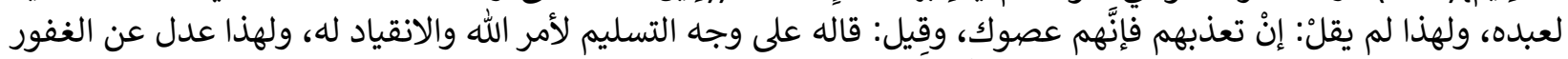

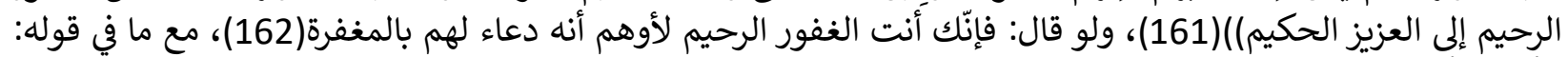

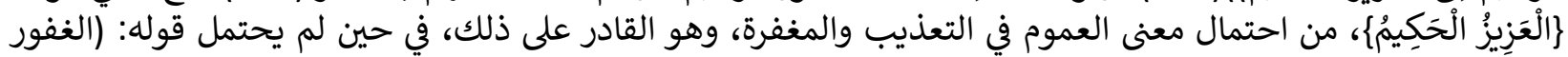

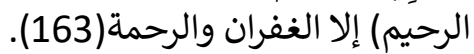

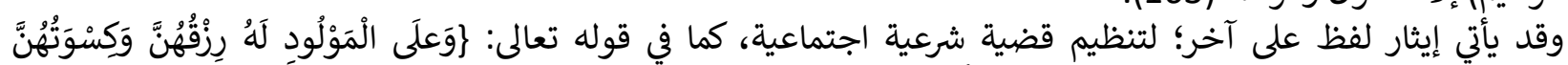

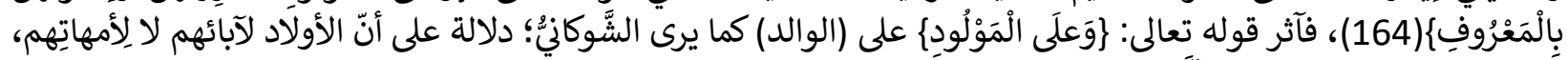

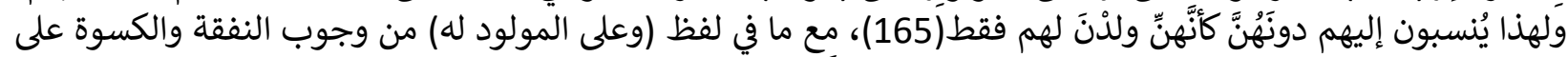

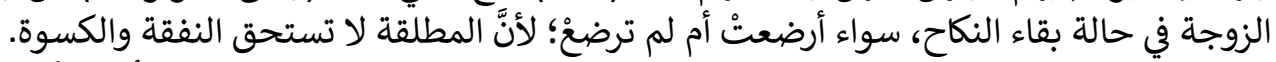

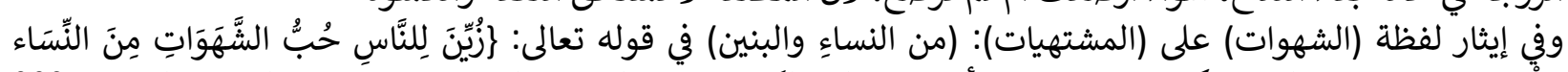

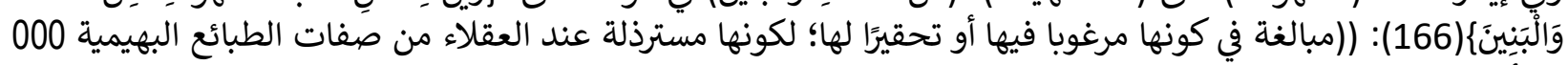

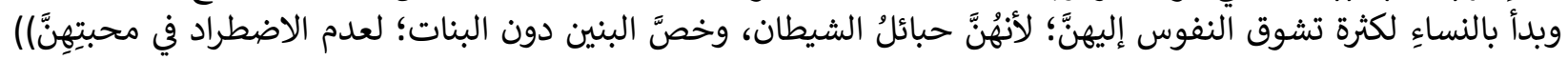

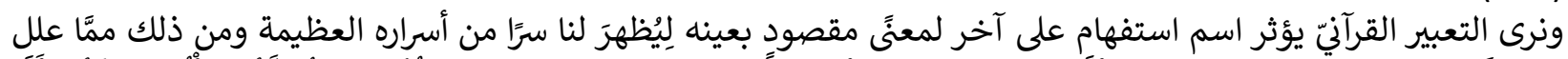

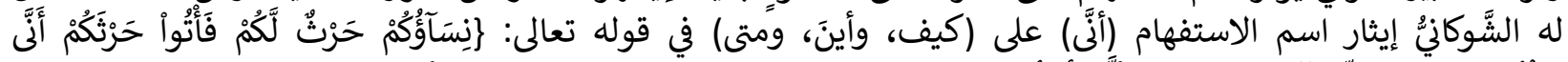

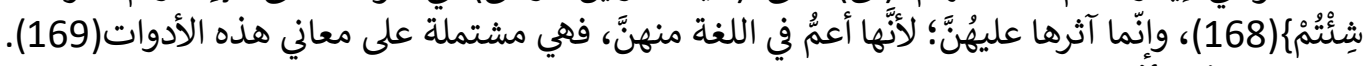

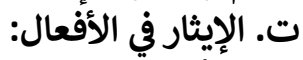

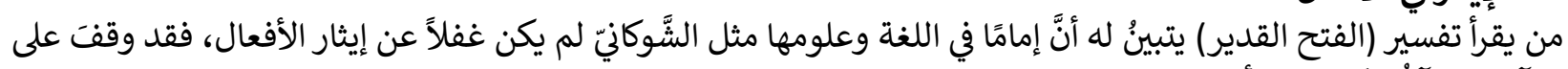

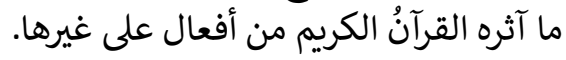

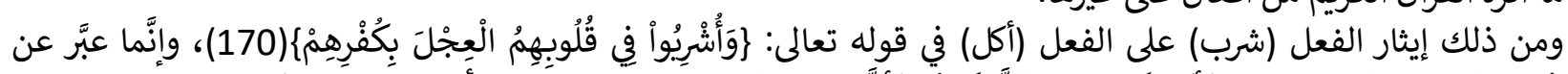

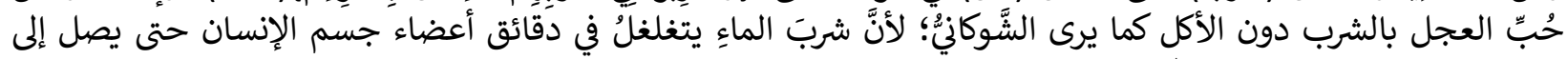

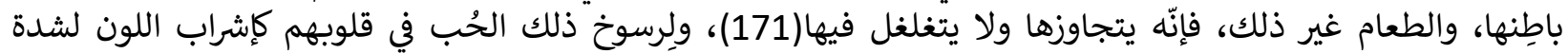
ملازمته (172).

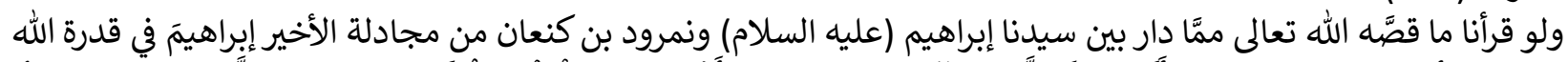

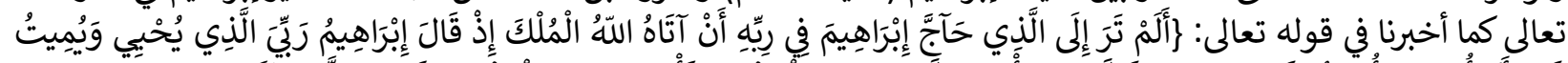

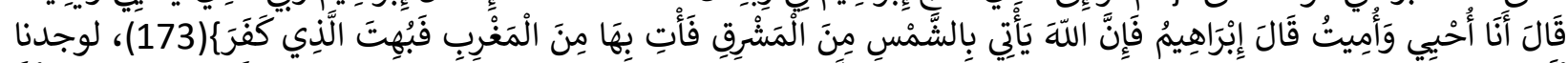

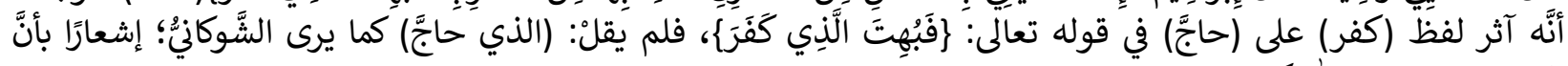

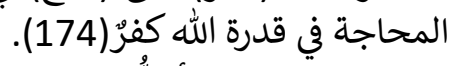

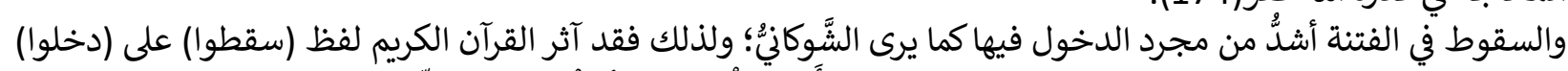

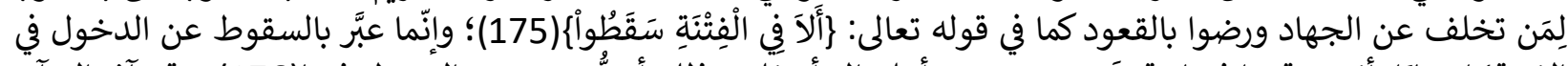

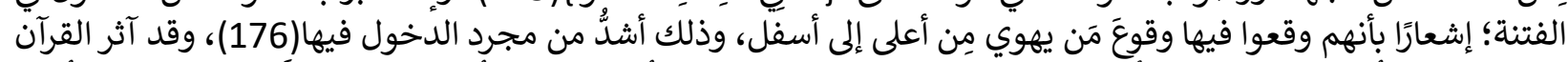

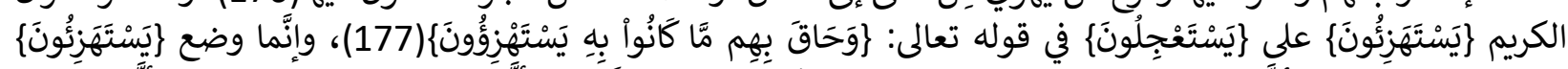

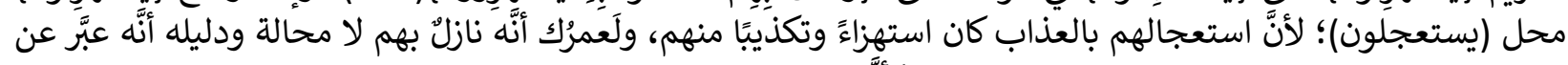

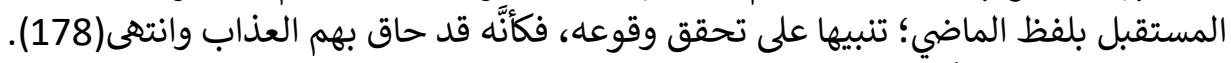

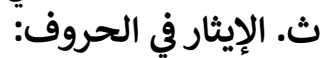

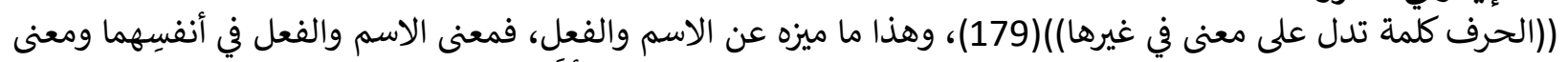

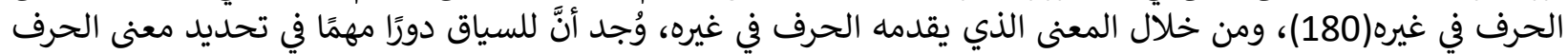

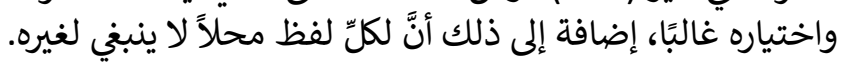




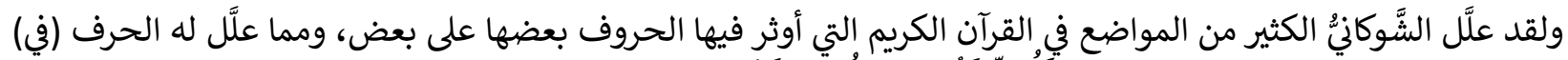

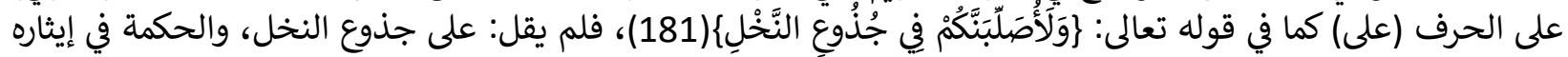

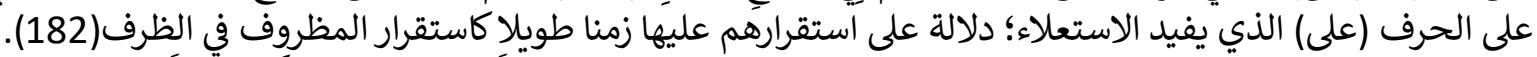

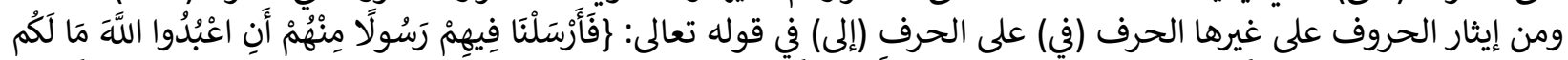

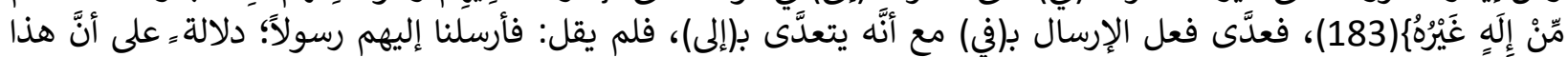

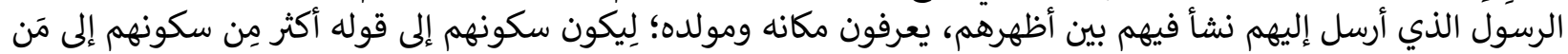
يأتيهم مِن غيول منير مكانهم(الذي (184).

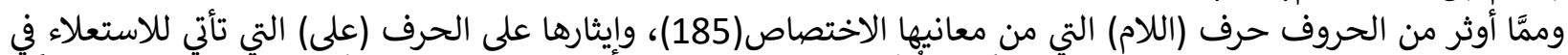

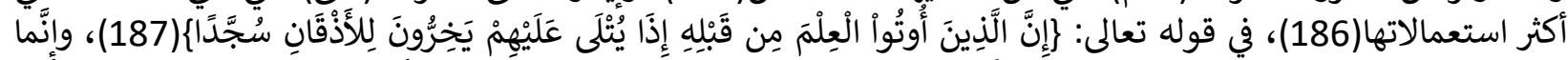

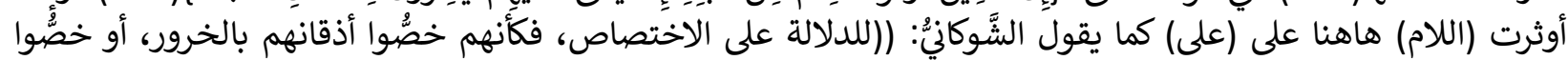

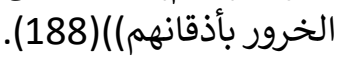

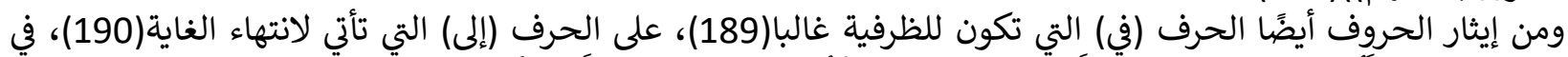

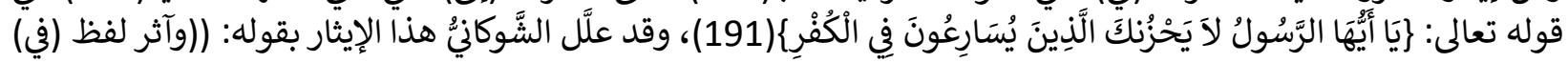
على لفظ (إلى)؛ للدلالة على استقرارهم فيه))(192).

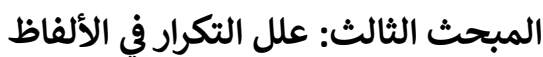

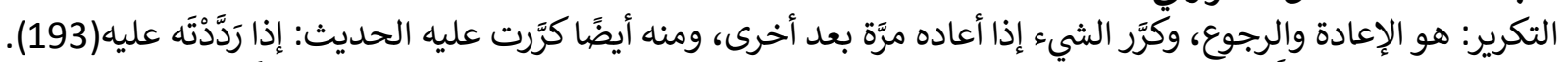

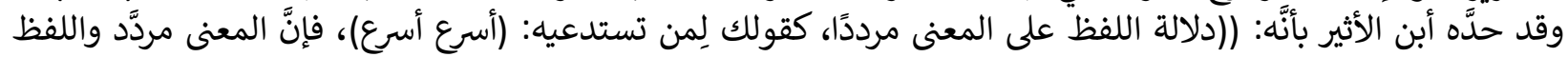

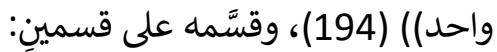

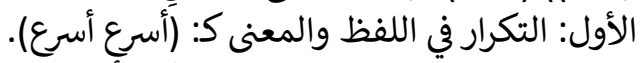

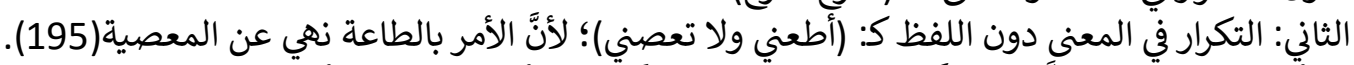

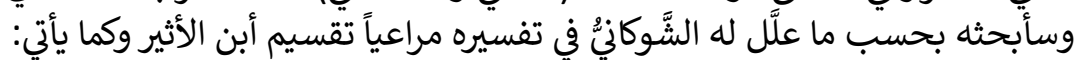

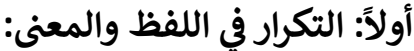

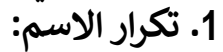

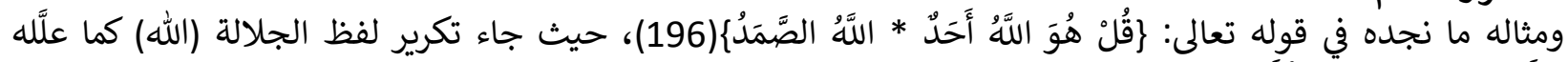

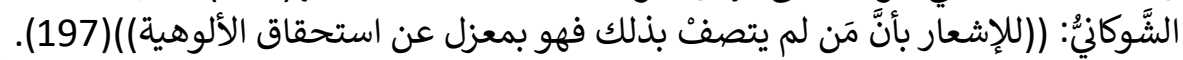

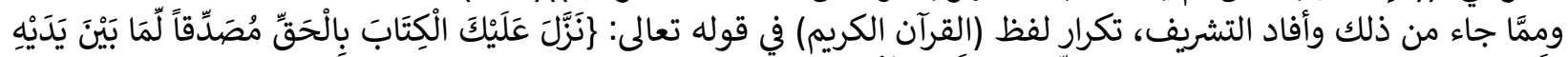

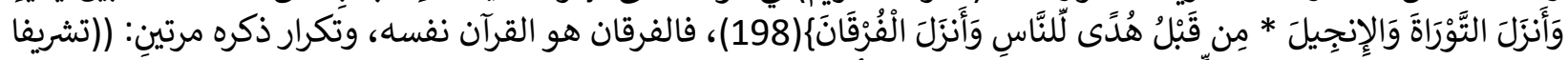

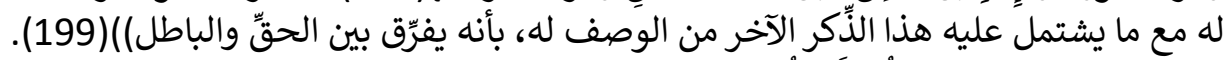

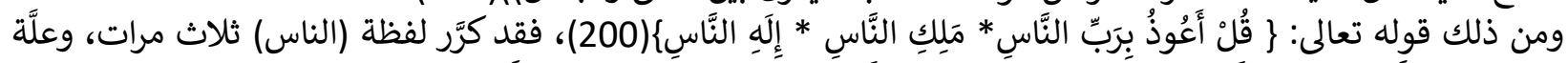

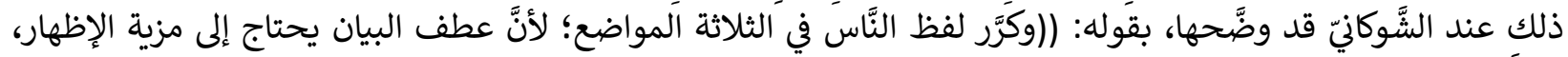

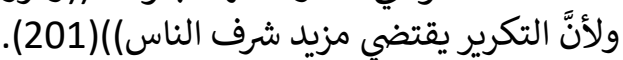

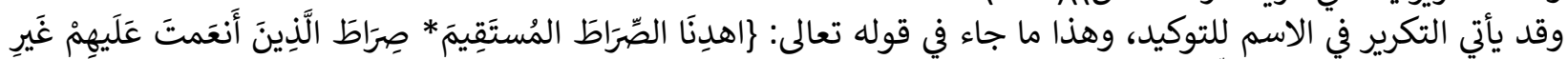

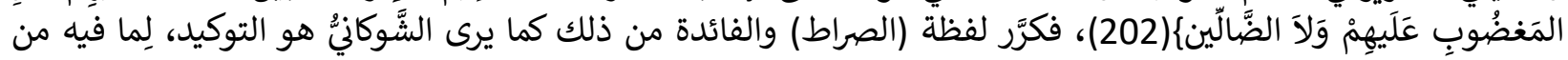
التثنية والتكرير(203). (203).

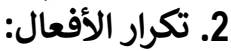

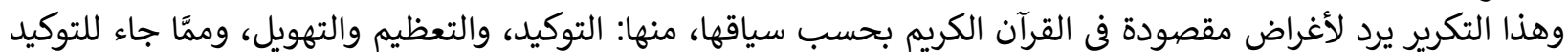

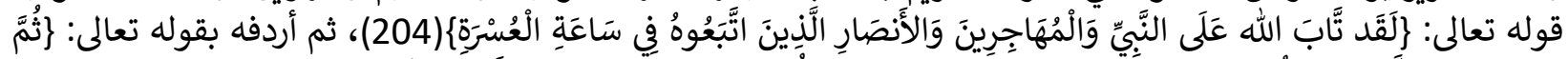

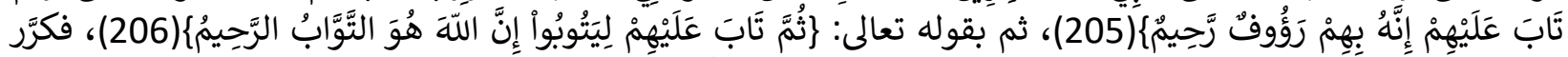

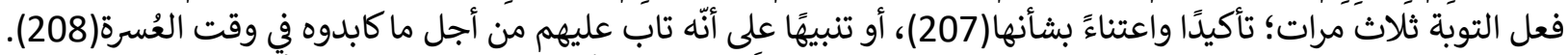

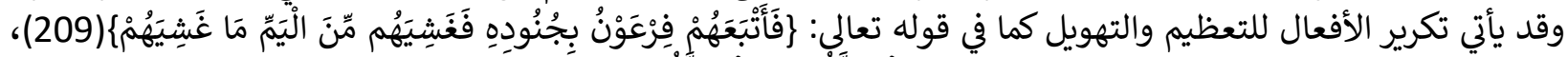

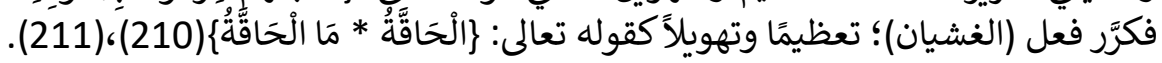
3. ت تكرار الحروف: (الفشيان:

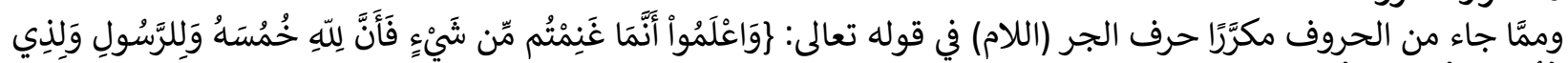

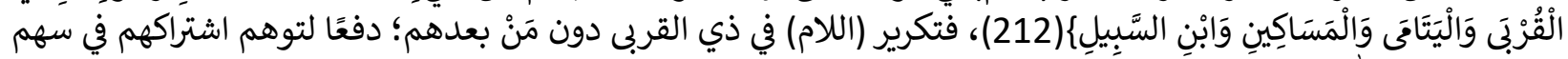

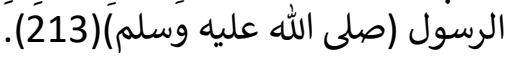




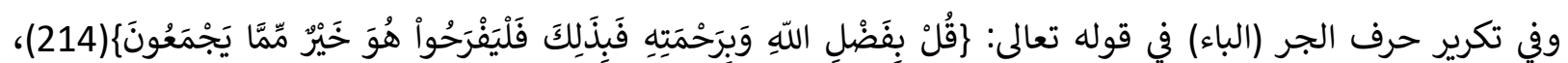

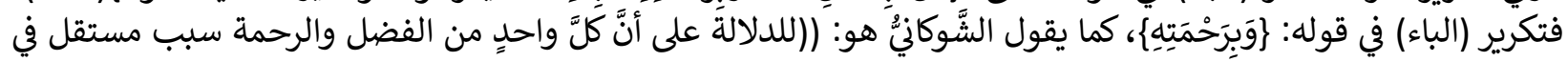

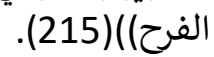

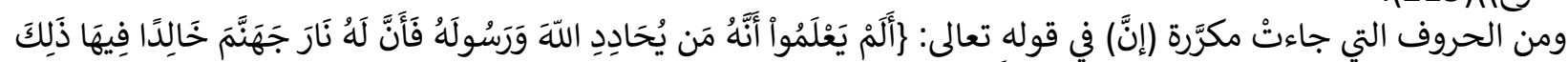

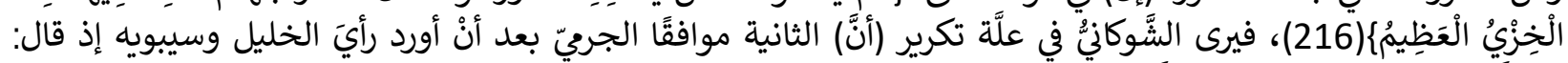

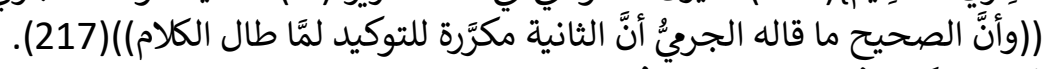

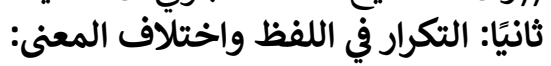

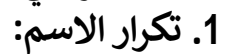

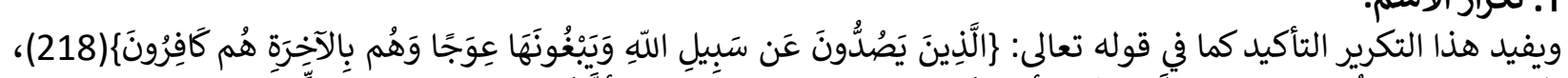

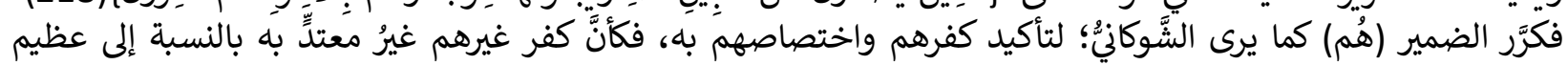
كفرهم(219).

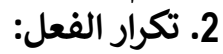

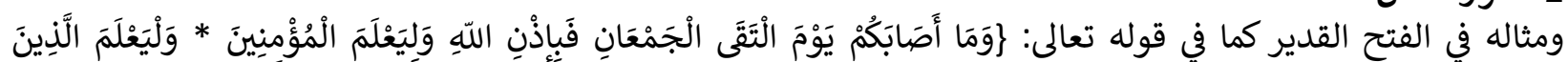

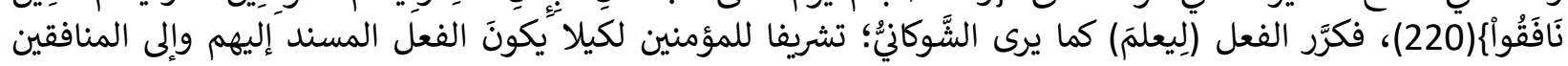
سواء(221).

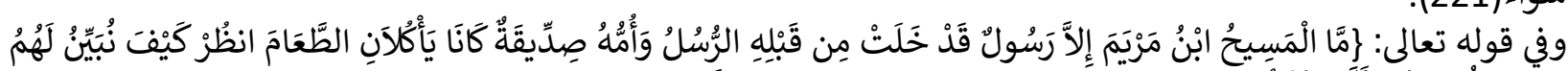

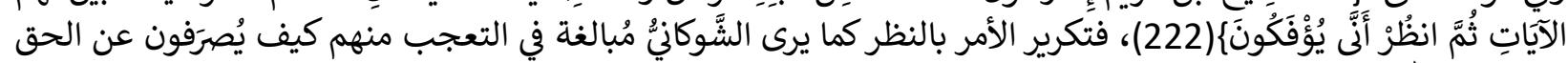

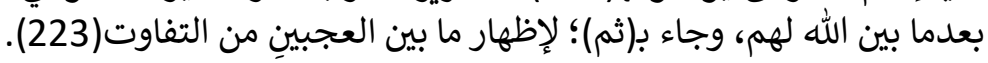

الخاتمة

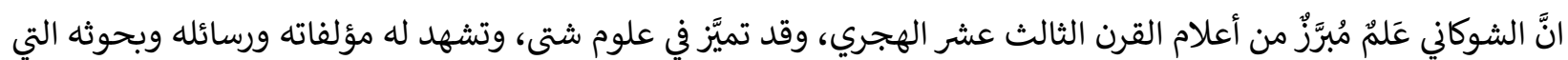

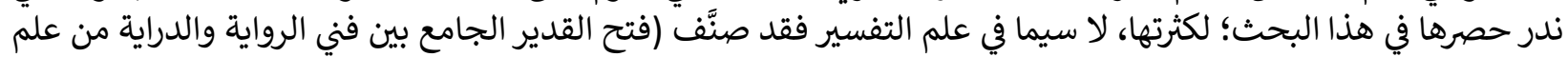

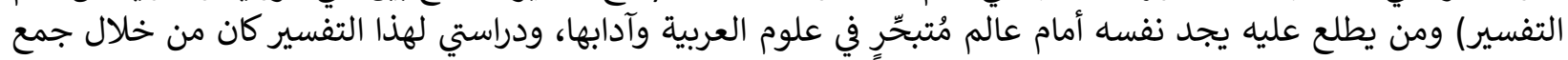

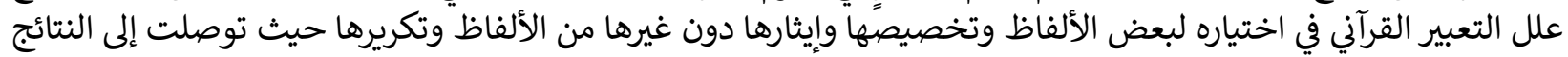

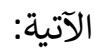

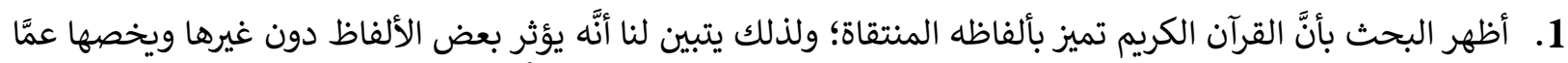

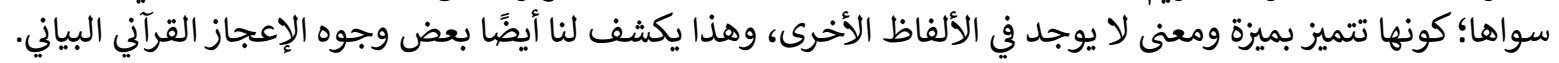

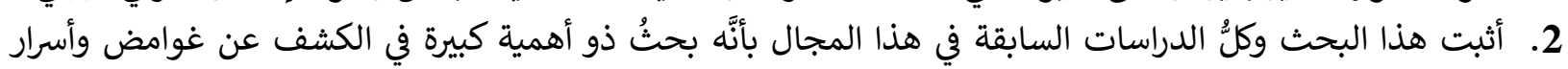
التعبير القرآني المعجز.

3. أظهر البحث بأنَّ كلَّ حركة أو حرف أو كلمة المَل في القرآن الكريم لها فائدة عظيمة، والعقل البشري عاجز إلى الوصول إلى أكثرها إلا القليل.

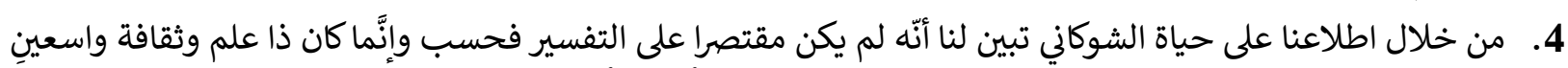

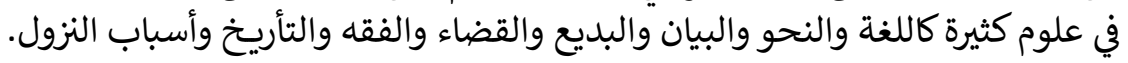

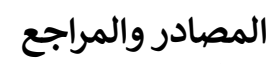
القرآن الكريم مصدر العربية الأول العرل

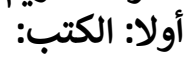

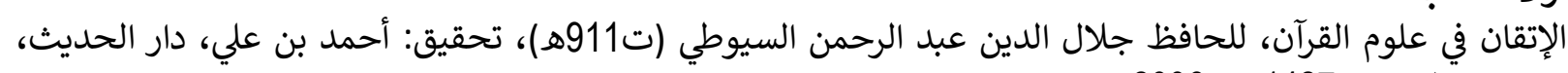

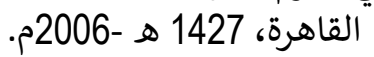

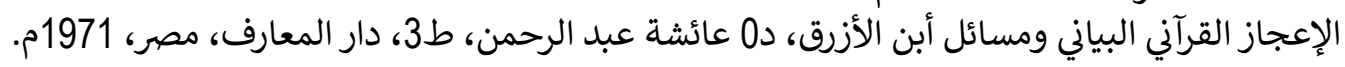

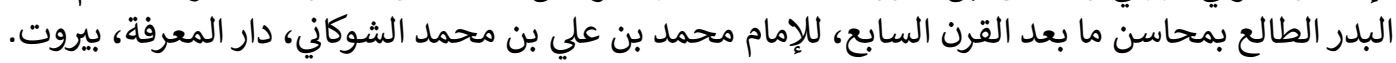

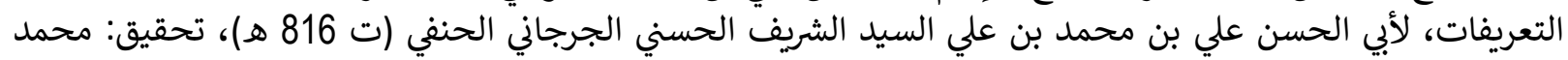

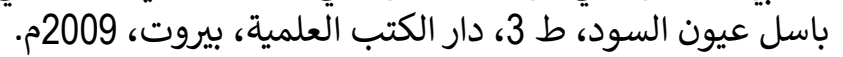

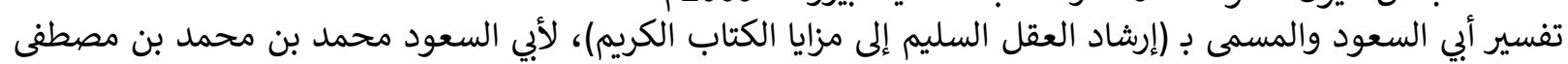

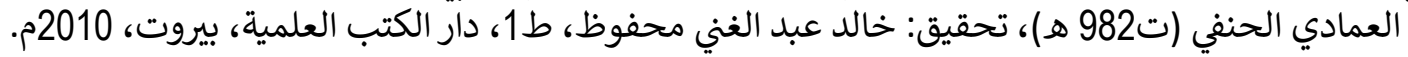


تفسير البحر المحيط، لأثير الدين أبي عبد الله بن يوسف بن علي بن حيان التيان الأندلسي الغرناطي (ت745هـ)، د. عبد الرزاق

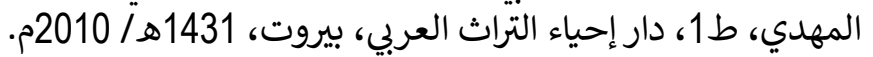

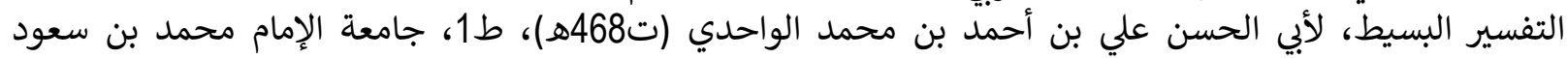

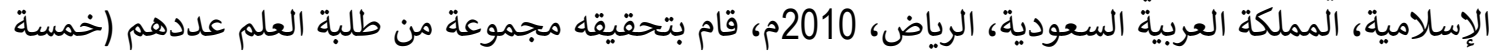

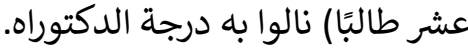

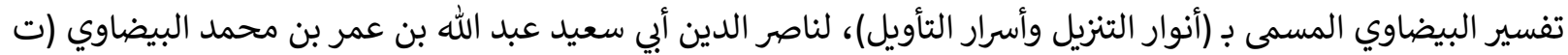

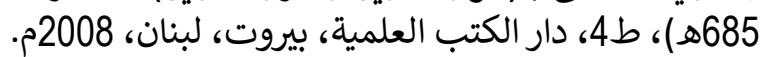

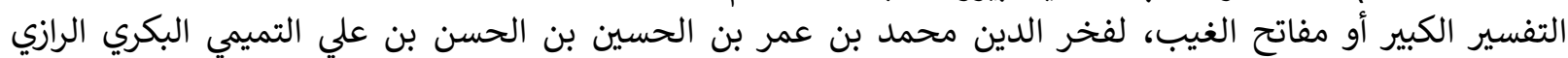

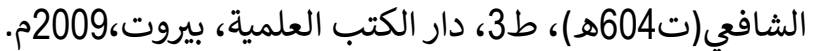

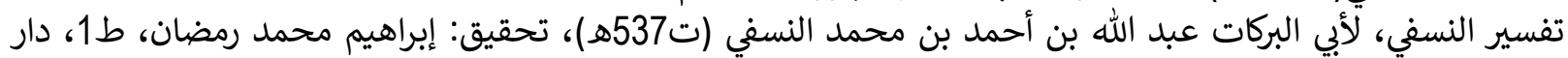

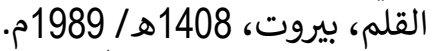

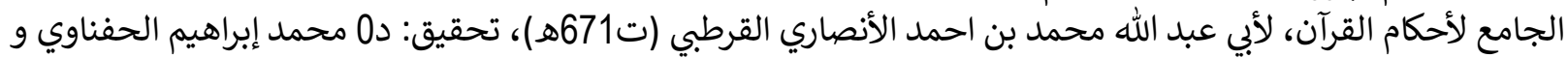

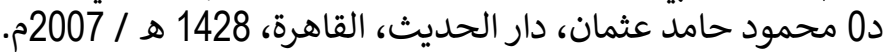

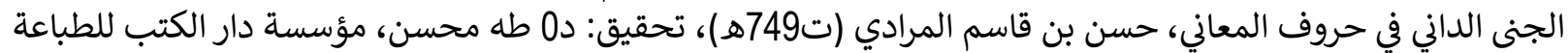

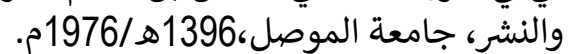

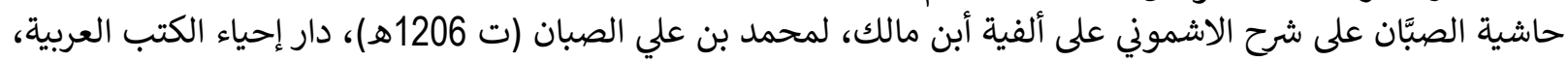

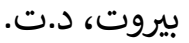

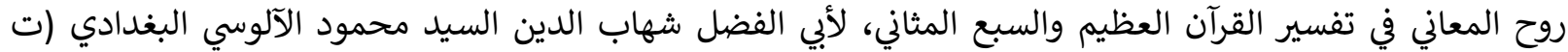

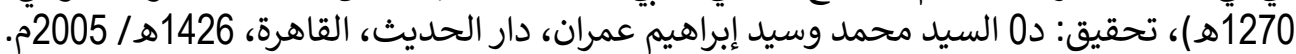

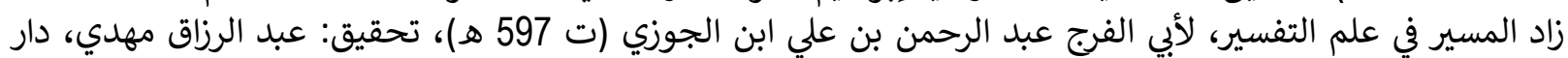

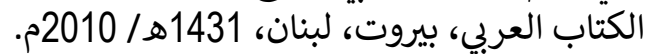

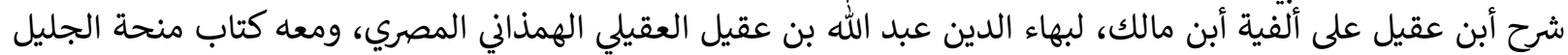

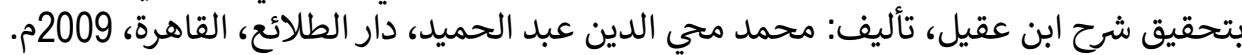

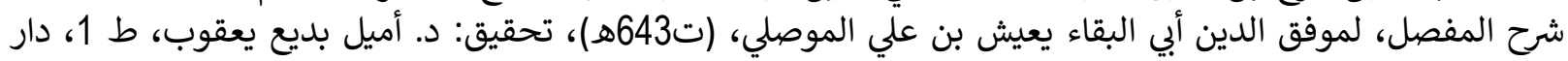

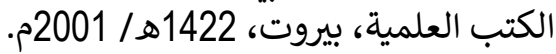

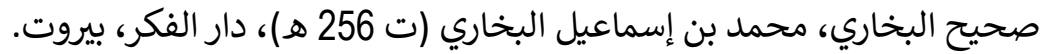

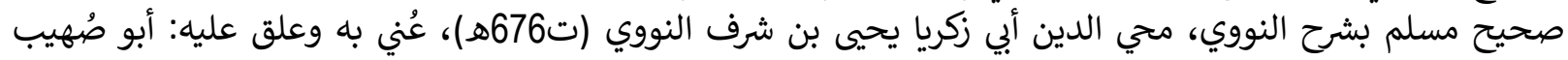

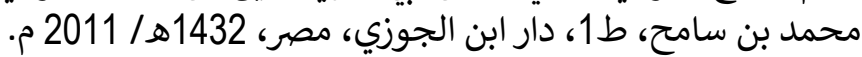

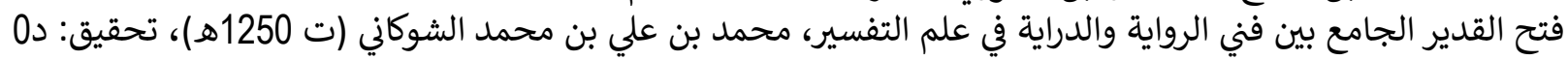

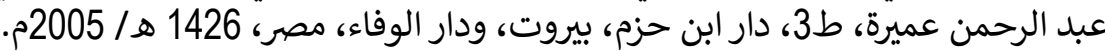

الفروق اللغويَّة، لأبي هلال العسكري (ت400هـ)، تحقيق: محمد باسل عيون الوفئ السود، ط2، دار الكتب العلمية، بيروت، 2010م. لأبن.

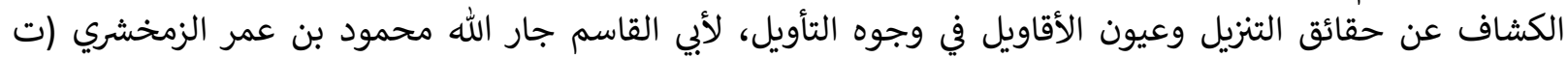

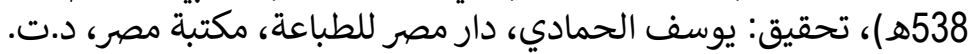

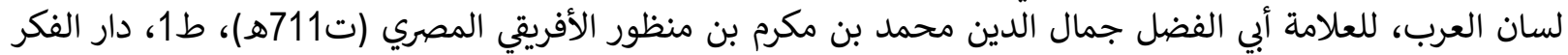

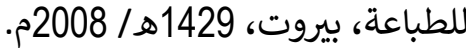

المثل السائر في أدب الكاتب والشاعر، ضياء الدين الدين بن الأثير (ت637هـ)، تحقيق: محمد مجي الدين عبد الحميد، المكتبة

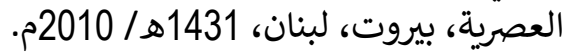

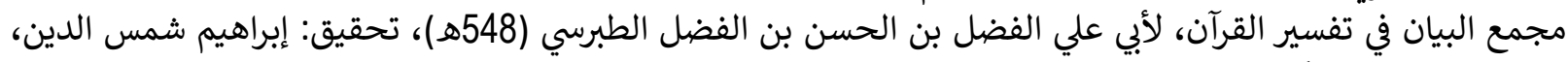

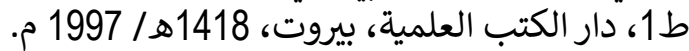

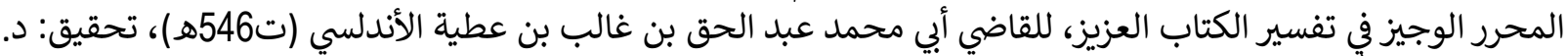

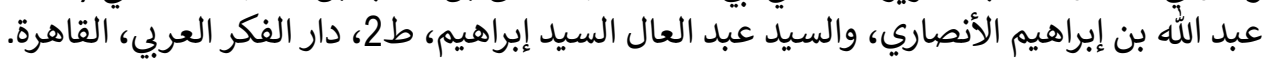

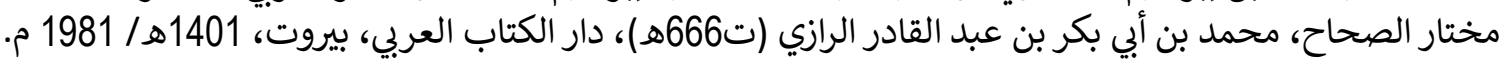

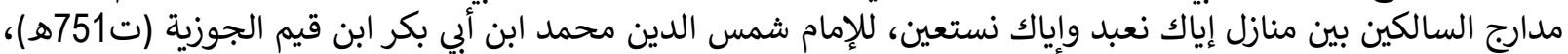

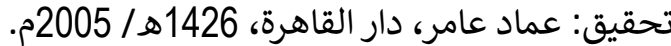

معاني القرآن وأعرابه، لأبي إسحاق عابر، دار إبراهيم بن السري الزجاج (ت311هـ)، تحقيق: عبد الجليل عبده شلبي، دار الحديث،

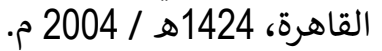


معاني القرآن، لأبي زكريا يحيى بن زياد الفراء (ت207هـ)، تحقيق: د. عبد الفتاح إسماعيل، وأحمد يوسف نجاتي، ومحمد علي النجار، دار السرور.

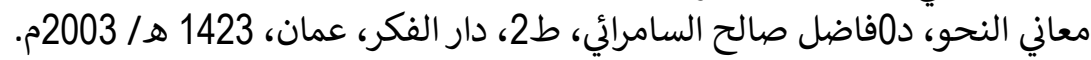

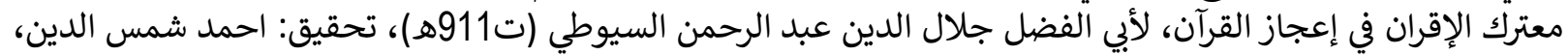

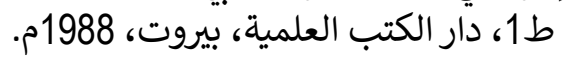

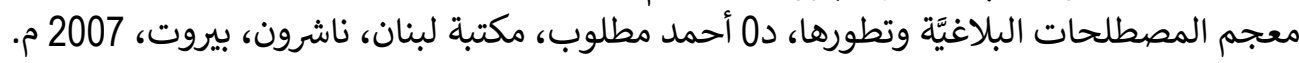

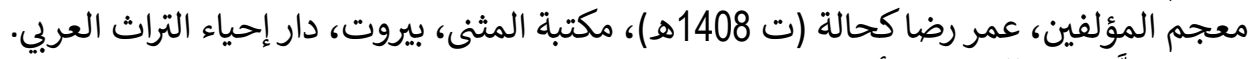

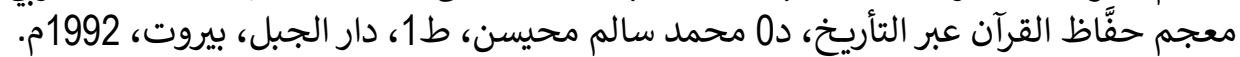

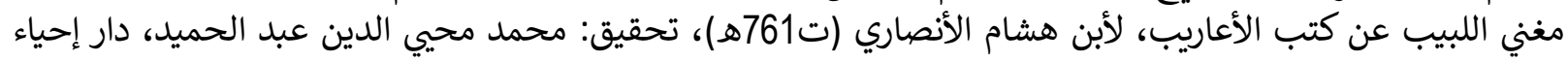

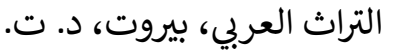

المقتضب، لأبي العباس محمد بن يزيد المبرد (ت285هـ)، تحقيق: عبد الخالق عظيمة، عالم الكتب، بيروت، 1431 هـ /

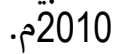

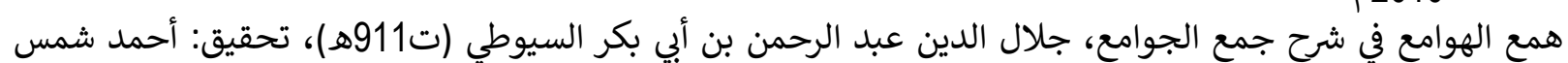
الدين، ط2، دار الكتب العلمية، بيروت، الجية العاعل 1427هـ / 2006 م.

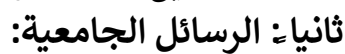

علل التعبير القرآني عند الرازي فائية في التفسير الكبير، د. أحمد جمعة محمود الهيتي، أطروحة دكتوراه، كلية الآداب، جامعة بغداد، 1420هـ/ 1999م. 


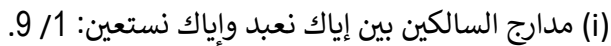
(2) ينظر: البدر الطالع:1 / 481، 4اكين والفتح القدير (مقدمة المحقق): 12/1.

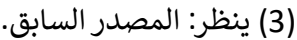

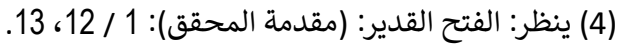

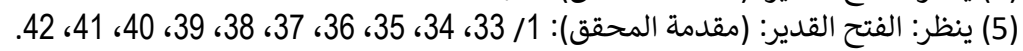

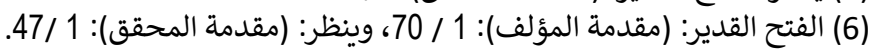

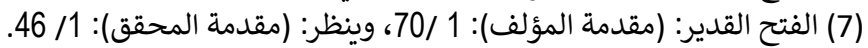

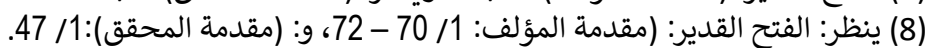

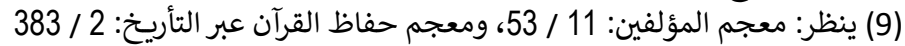
(10) - (10) سورة آل عمران، آية: 7.

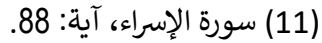

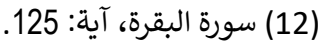

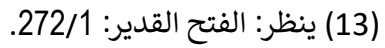

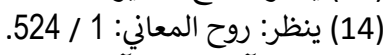

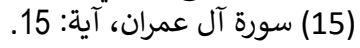

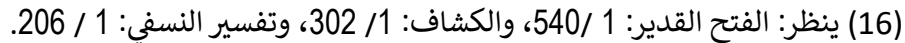

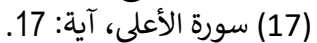

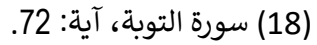

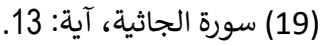

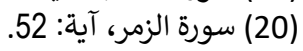
(21) - (21) سورة القصص، آية: 3.

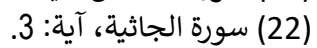
(23) ينظر: الفتح القدير: 5 / 8 8، و4 / / 209 201، 616. (24) (25) سورة النازعات، آية:45.

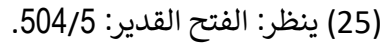
(26) سورة البقرة، آية: 172 (26)

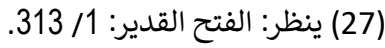
(28) (28) سورة التوبة، آية:

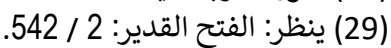

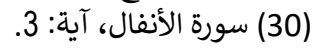

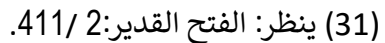

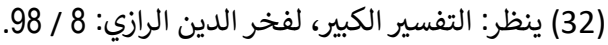

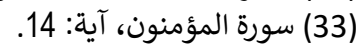

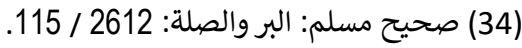

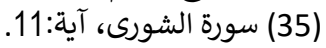

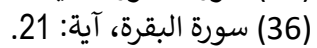

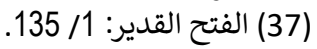

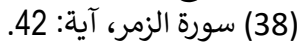
(39) سورة يونس، آية:

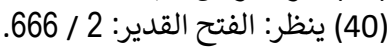

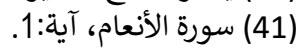

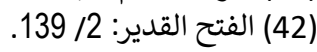

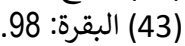

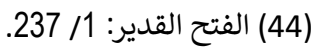

(45) ينظر: التفسير البسيط: 12 /3143، ومعاني القرآن وأعرابه، للزجاج: 3 / 116.

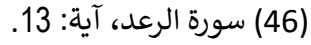

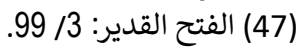
(48) ينظر: التفسير البسيط: 12/ القدر/ 314.

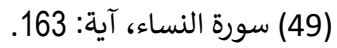

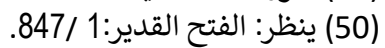
(51) ينظر: مجمع البيان، للطبرسي: 181/3. (52) سورة يونس، آية: 75. 


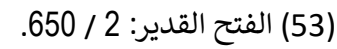

(54) سورة المؤمنون، آية: 65 (53) الفيرن

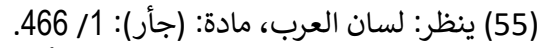

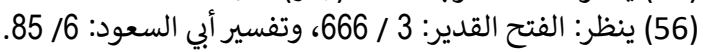

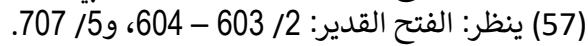

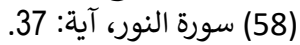

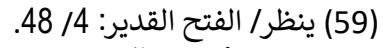

(60) سورة الأعراف، آية: 150 (61)

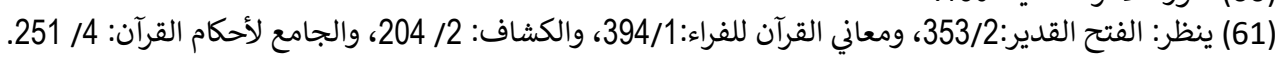

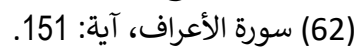

(63) سورة النحل، آية:

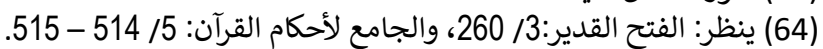

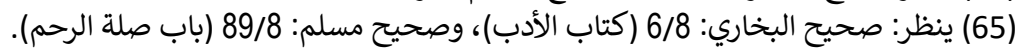

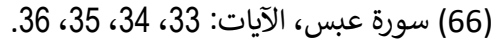

(67) سورة عبس، آية: 37 سورة الآنات

(68) ينظر: لسان العرب: 2 / 25 / 25.

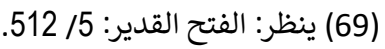

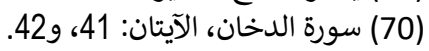

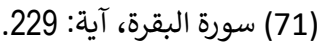

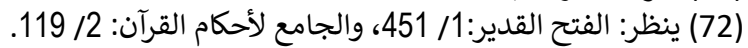

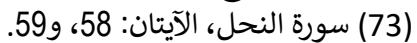

(74) سورة آل عمران، آية: 14 (73)

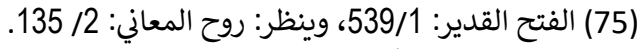

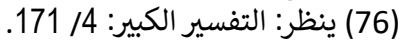

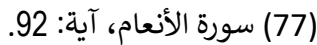

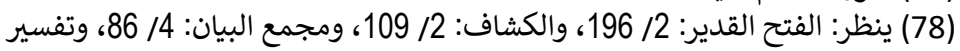

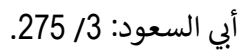

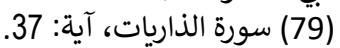

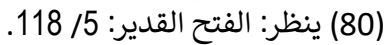

(81) سورة المؤمنون، آية: 19 (81)

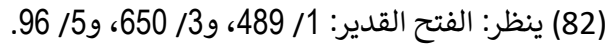

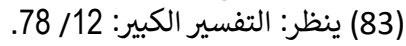

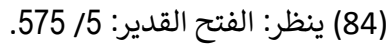

(86) سورة الأعراف، آية: 40 (85)

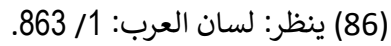

(87) ينظر: المصدر نفسه:

(88) ينظر: الفتح القدير: 289/2 (89)

(89) ينظر: الفتح القدير: 289/ 289، والتفسير: الفير الكبير: 284.

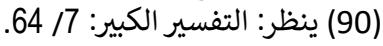

(92) (91) سورة النمل، آية:

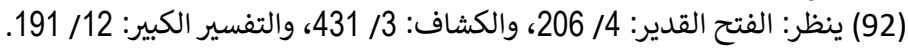

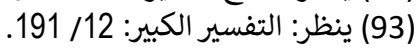

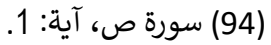

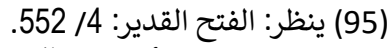

(96) ينظر: الجامع لأحكام القرآن: 8 / 8 / 123 (95) 14

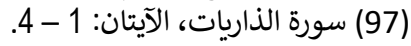

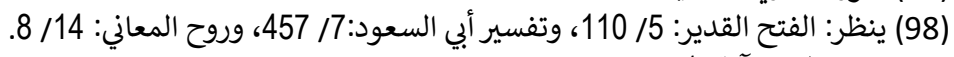

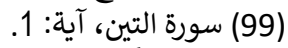

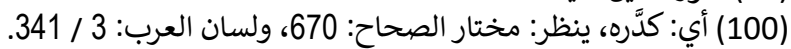

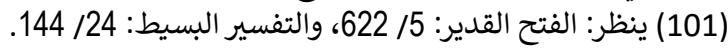

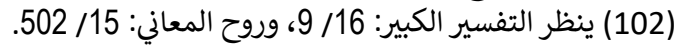

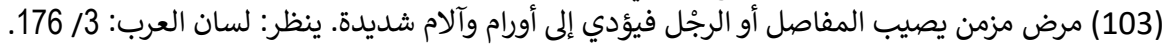

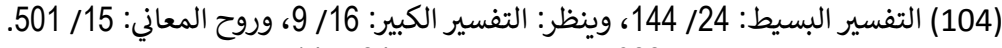

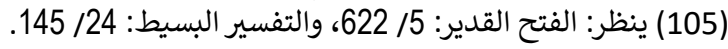




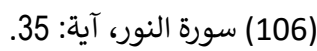

(107) سورة العصر، الآيتان: 1 - 2 (108) سورة

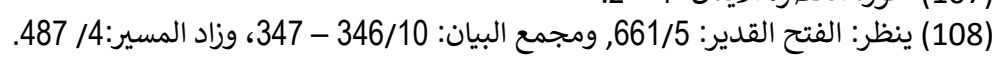

(109) سورة يونس، آية: 25.

(110) ينظر: الفتح القدير: 2/ 616، 610، والجامع لأحكام القرآن: 4/ 633.

(111) سورة يونس، آية: 87 الفير:

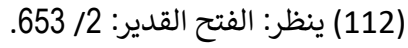

(113) سورة الفلق، الآيات: 1 - 1 - 5.

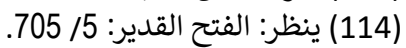

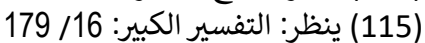

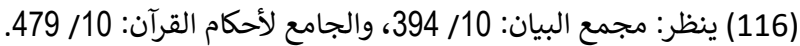

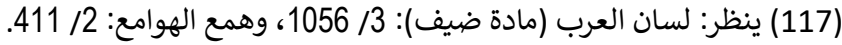

(118) (118) التعريفات: 32 (118)

(119) شرح أبن عقيل: 320/3.

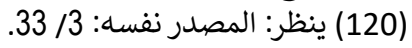

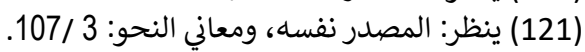

(122) سورة الأعراف، آية:

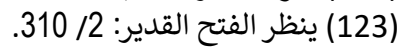

(124) ينظر: الكشاف: 2/ 168، 123، والتفسير الكبير: 17/ 133.

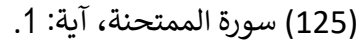

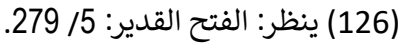

(127) سورة الهمزة، آية:

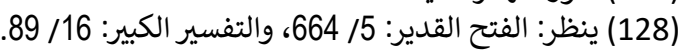

(129) سورة المدثر، الآيتان: 28 - 29 (128)

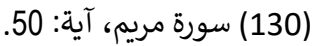

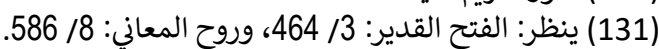

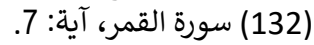

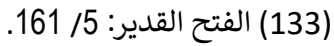

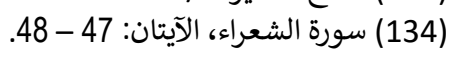

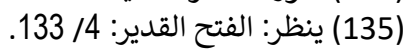

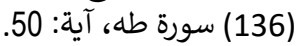

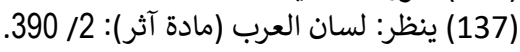

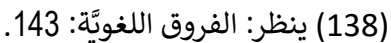

(139) (138) سورة يوسف، آية:

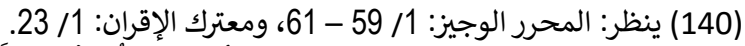

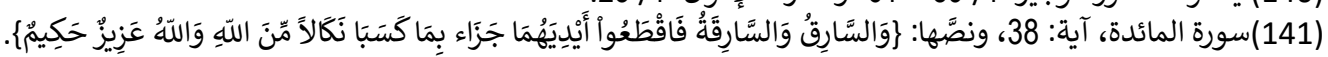

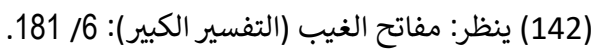

(143) ينظر: الأعجاز البياني للقرآن: 215 (142)

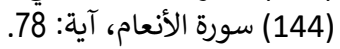

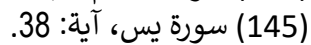

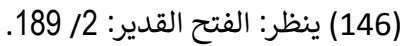

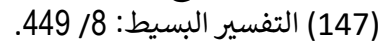

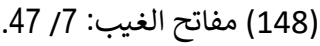

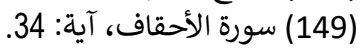

(150) (151) ينظر: الفتح القدير:

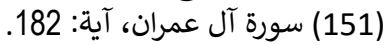

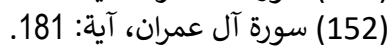

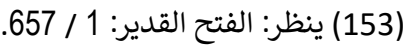

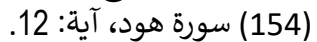

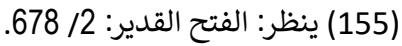

(156) (155) سورة النمل، آية: الفير: 70.

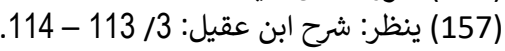

(158) سورة البقرة، آية:

(159) ينظر: الفتح القدير: 1/ 214، والكشاف: 1/ 145، والتفسير الكبير: 2/ 119. 
(160) سورة المائدة، آية: 118 (1618)

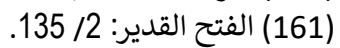

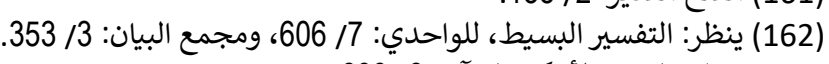

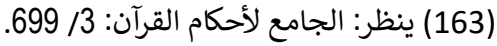

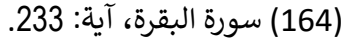

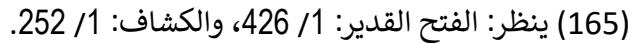

(166) سورة آل عمران، آية: 14 (165)

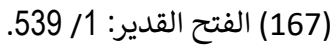

(168) سورة البقرة، آية: 223.

(169) ينظر: الفتح القدير: 168 آية: 223، 996، والمحرر الوجيز: 2/ 256، والجامع لأحكام القرآن: 2/ 84.

(170) (171) سورة البقرة، آية:

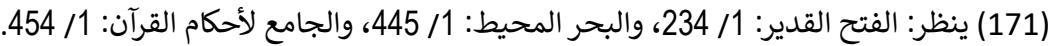

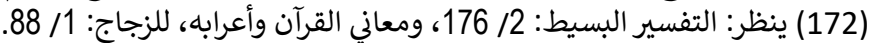

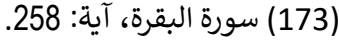

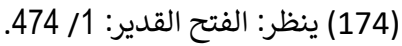

(175) سورة التوبة، آية: 49 (176)

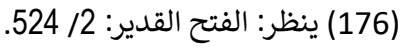

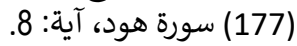

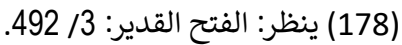

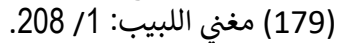

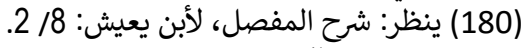

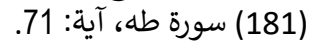

(182) ينظر: الفتح القدير: 3181/ آلة 515، والتفسير البسيط: 14/ 464، وتفسير أبي السعود: 439/5 وروح المعاني: 753/8.

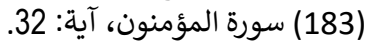

(184) ينظر: الفتح القدير: 3 / 656 - 657 - 653

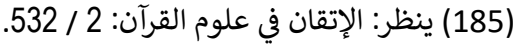

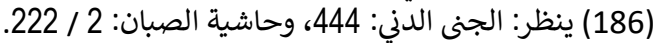

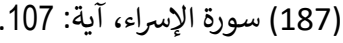

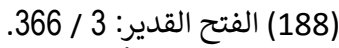

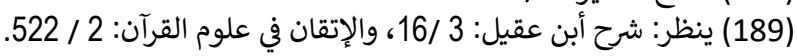

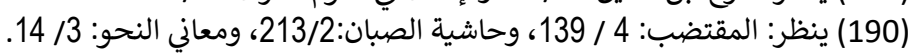

(191) سورة المائدة، آية: 41 (192)

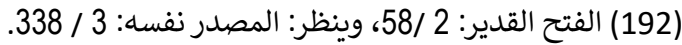

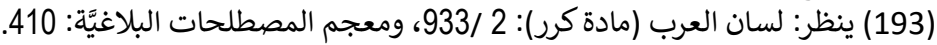

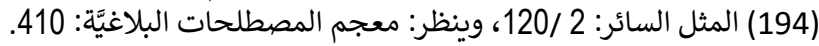

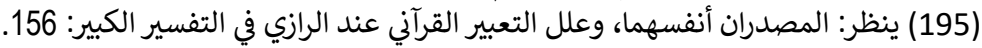

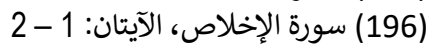

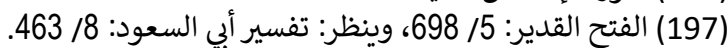

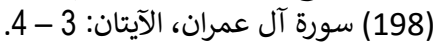

(199) (198) الفتح القدير: 1 / / 1925.

(200) سورة الناس، الآيات: 1 - 1 - 3 الفند

(201) الفتح القدير: 5/ 707، وينظر: التورة التفسير الكبير: 181/16، وتفسير أبي السعود: 471/8.

(202) سورة الفاتحة، الآيتان: 6 - 7 الفين الفير:

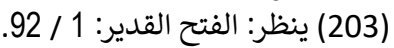

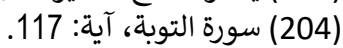

(205) (205) السورة والآية نفسها. آنة:

(206) سورة التوبة، آية: 118 (205)

(207) ينظر: الفتح القدير: 2 / 2084 (2064)

(208) ينظر: تفسير البيضاوي: 1 / / 484 (207)

(209) سورة طه، آية: 78 (208)

(210) سورة الحاقة، الآيتان: 1 -2110.

(211) ينظر: الفتح القدير: 3 / 518 (210.

(212) سورة الأنفال، آية: 41 (2112.

(213) ينظر: الفتح القدير: 2/ سورة الأفالة 446.

March 2021, Volume 3, Issue 3

p. 498-515 
(214) سورة يونس، آية: 58.

(215) الفتح القدير: 2 / 636.

(216) سورة التوبة، آية: 63 (215.

(217) الفتح القدير: 2 / 536.

(218) سورة هود، آية: 19.

(219) ينظر: الفتح القدير: 218/ 684، والكشاف: 395/2، والتفسير الكبير: 194/ 164، وتفسير أبي السعود: 310، 310، والجامع لأحكام القرآن: 5 /

(220)

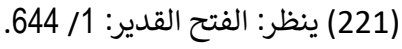

(222) سورة المائدة، آية: 75.

(223) ينظر: الفتح القدير: 2 / 222. 